\title{
Nanoparticle Surface Functionalization: How to Improve Biocompatibility and Cellular Internalization
}

\author{
Gennaro Sanità*, Barbara Carrese and Annalisa Lamberti* \\ Department of Molecular Medicine and Medical Biotechnology, University of Naples Federico II, Naples, Italy
}

The use of nanoparticles (NP) in diagnosis and treatment of many human diseases, including cancer, is of increasing interest. However, cytotoxic effects of NPs on cells and the uptake efficiency significantly limit their use in clinical practice. The physico-chemical properties of NPs including surface composition, superficial charge, size and shape are

Edited by:

Henri Vahabi,

Université de Lorraine, France

Reviewed by:

Sachin Kumar Deshmukh,

University of South Alabama

United States

Xijian Liu,

Shanghai University of Engineering

Sciences, China

Longgang Wang,

Yanshan University, China

*Correspondence:

Gennaro Sanità

gennaro.sanita@unina.it

Annalisa Lamberti

annalisa.lamberti@unina.it

Specialty section:

This article was submitted to

Molecular Diagnostics

and Therapeutics,

a section of the journal

Frontiers in Molecular Biosciences

Received: 24 July 2020 Accepted: 05 November 2020

Published: 26 November 2020

Citation:

Sanità G, Carrese $B$ and Lamberti A (2020) Nanoparticle

Surface Functionalization: How to Improve Biocompatibility

and Cellular Internalization.

Front. Mol. Biosci. 7:587012.

doi: 10.3389/fmolb.2020.587012 considered the key factors that affect the biocompatibility and uptake efficiency of these nanoplatforms. Thanks to the possibility of modifying physico-chemical properties of NPs, it is possible to improve their biocompatibility and uptake efficiency through the functionalization of the NP surface. In this review, we summarize some of the most recent studies in which NP surface modification enhances biocompatibility and uptake. Furthermore, the most used techniques used to assess biocompatibility and uptake are also reported.

Keywords: nanoparticles, toxicity, biocompatibility, uptake, functionalization

\section{INTRODUCTION}

Nanoparticles (NPs) are ultrafine particles with a size between 10 and $500 \mathrm{~nm}$ composed of different organic and/or inorganic materials (Jeevanandam et al., 2018). These particles have been widely studied because of their unique properties and find suitable application in a great number of biomedical fields like biomolecule detection, vaccines, regenerative medicine, and tissue engineering, gene and drug delivery, cancer therapy, high accuracy diagnosis, and theranostics (Rudramurthy and Swamy, 2018).

When NPs are used in biomedical applications two very important characteristics must be considered: toxicity and cellular uptake (Rees et al., 2019; Santos-Rasera et al., 2019; Zhang C. et al., 2019). In fact, the biocompatibility of NPs is one of the most critical characteristics of nanoplatforms to be suitable for biomedical purposes (Elmowafy et al., 2019; Liu et al., 2020), and the NPs capability to be internalized by target cells, compared to not-target cells, is a very important goal (Emami et al., 2019; Khan et al., 2019; Khanna et al., 2019).

The use of NPs has grown exponentially in the last 15 years especially for cancer treatment, because of their capability to perform high precision tasks, such as the delivery of drugs and imaging contrast agents (CAs) directly to tumor cells (Panebianco et al., 2019; Zhang X. et al., 2019), by using a large number of molecular targets (Yoo et al., 2019). In particular, the accumulation of nanocarriers in cancer cells can occur through two different mechanisms: passive and active targeting. In passive targeting, NPs accumulate in the proximity of the tumor site as result of 
the altered permeability of tumor blood vessels. This phenomenon, known as the enhanced permeability retention (EPR) effect, permits the passive accumulation of NPs to solid tumors and/or metastatic sites, simply through their particular physical properties including size, shape, and superficial charge (Maeda, 2015). Active targeting exploits the biofunctionalization of the NPs surface by using ligands with a strong affinity and specificity for overexpressed receptors and molecules on the tumor cells (Bertrand et al., 2014; Yoo et al., 2019) or secreted proteins in the tumor microenvironment (TME) (Huai et al., 2019). Active and passive targeting are phenomena often occur simultaneously, and one does not preclude the other (Figure 1).

The use of NPs for active targeting of drugs and/or contrast agents is based on the interaction of properly modified NPs surface with a molecular target overexpressed by cells and tissues. The molecules used to modify the NPs surface include small proteins, peptides, antibodies, aptamers, and oligosaccharides (Large et al., 2019; Yoo et al., 2019). Furthermore, the biochemical modification of the NPs surface with these specific targeting ligands is often necessary to reduce toxicity (as widely applied for silver NPs) and to increase their stability in biological fluids (Guerrini et al., 2018; Borowik et al., 2019). An example is represented by the use of human albumin, whose presence on the NPs surface reduces toxicity and achieves active targeting at the same time ( $\mathrm{Li}$ D. et al., 2018; Sanità et al., 2020). The chemical modification of the NPs surface is a stepby-step process that requires chemical-physical and biological characterization for each step. Transmission electron microscopy (TEM), scanning electron microscopy (SEM), Fourier transform infrared spectroscopy (FTIR), dynamic light scattering (DLS), and $\zeta$-potential analysis are some of the most useful and simple techniques used to study shape, size, chemical composition, and superficial charge of NPs (Rea et al., 2014; Silvestri et al., 2019). In contrast, the biological evaluation of NPs requires a more complex analysis with the assessment of numerous variables depending on the experimental model, conditions, and other specific parameters (Terracciano et al., 2015; Barot et al., 2020; Sanità et al., 2020). In conclusion, it is crucial to consider the effects of the NPs surface modification on stability, uptake, and biocompatibility to achieve an efficient nanoplatform for biomedical applications.

The focus of this review is to summarize the most used techniques to evaluate NPs toxicity and uptake and to describe the most useful strategies to avoid these issues through the modification of the NPs surface.

\section{THE ROLE OF NANOPARTICLES IN CANCER DISEASE}

NPs can be applied to cancer for two main purposes: diagnosis and therapy (Borkowska et al., 2020; Tammaro et al., 2020). The usage of nanoplatforms for diagnosis can be classified by two different approaches: biomolecule detection and imaging techniques. Biomolecule detection is based on the identification of tumor markers that are often present in a very small amount in biological samples (Marrugo-Ramírez et al., 2018). The possibility to modify NPs by specific ligands with high affinity for these markers can improve the identification and quantification of desired compounds (Kiplagat et al., 2019).

Medical imaging techniques have evolved very quickly over the past 20 years, overall in cancer disease, to identify very little tumor masses for an early diagnosis (Kumar et al., 2019; Li et al., 2019c; Vaidya et al., 2019). This evolution has occurred through the combined use of classical imaging techniques (like MRI, PET and SPECT) with NPs (Forte et al., 2019; Song et al., 2020) and advancing toward the use of innovative imaging techniques like photoacoustic (PA), surface-enhanced Raman scattering (SERS), and near infrared light up-conversion (NIR-Up) (Silvestri et al., 2019; Ge et al., 2020; Kim et al., 2020). All these techniques are very useful in combination with NPs-mediated delivery in order to accumulate CAs in the tissues of interest.

For cancer therapy, there are currently numerous agents available depending on the disease stage, location, type of tissue, age, and conditions of the patient (Reece-Mills et al., 2016; Cohen, 2017). The use of classical chemotherapeutic compounds, radiation, and surgical interventions are still useful and widely used for treating tumors, but the side effects are often a serious concern (Oun et al., 2018; Schirrmacher, 2019). Furthermore, the recurrence of cancer due to the incomplete removal of malignant cells is a major reason of poor prognosis (Chihara et al., 2017; Corrado et al., 2017). The use of NPs for an early and precise identification of cancer cells can help to avoid delayed diagnosis, and the specific delivery of a limited amounts of drug directly to cancer cells can effectively reduce chemotherapyrelated side effects (Parvanian et al., 2017; Zhao et al., 2018; Chen Y. et al., 2019). At the same time, the usage of NPs can be useful to bypass the drug resistance of some tumors, like melanoma (Naves et al., 2017; Avagliano et al., 2019). In this scenario, the surface modification of NPs represents an important strategy to successful develop specific and biocompatible nano-platforms for precise and sensitive therapy and/or diagnosis.

\section{METHODS FOR NPS SURFACE MODIFICATION AND UPTAKE AND BIOCOMPATIBILITY EVALUATION}

The surface modification of nanoparticles is a powerful methodology to fix or attenuate issues related to NPs toxicity and uptake, since both phenomena are closely related to the NPs surface composition.

\section{Surface Modifications: Covalent and Non-covalent Bonds}

The surface functionalization of NPs involves a process that aims to improve and/or add properties useful for the use of NPs in medical applications. Different types of nanomaterials have characteristic chemical properties and functional groups exposed on their surface to be used in the first steps of functionalization. Generally, the first phase of the surface modification is based on the use of homo- or hetero-bifunctional cross linkers to the aim to add an organic functional group ( $\mathrm{R}-\mathrm{NH}_{2}, \mathrm{R}-\mathrm{COOH}$, etc.), 


\section{NPs passive targeting}

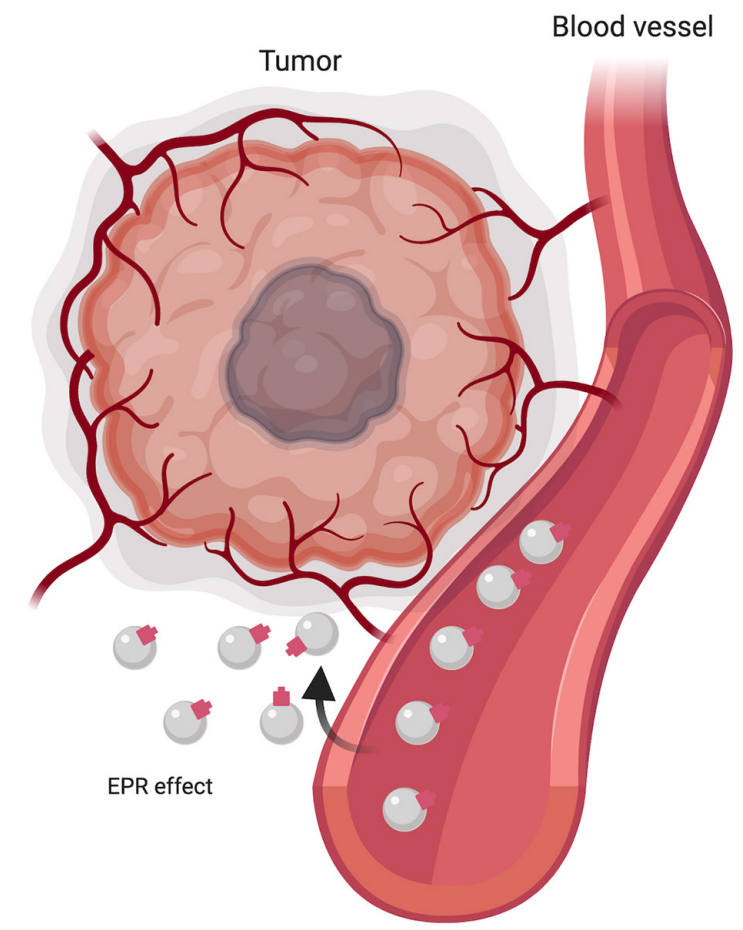

\section{NPs active targeting}

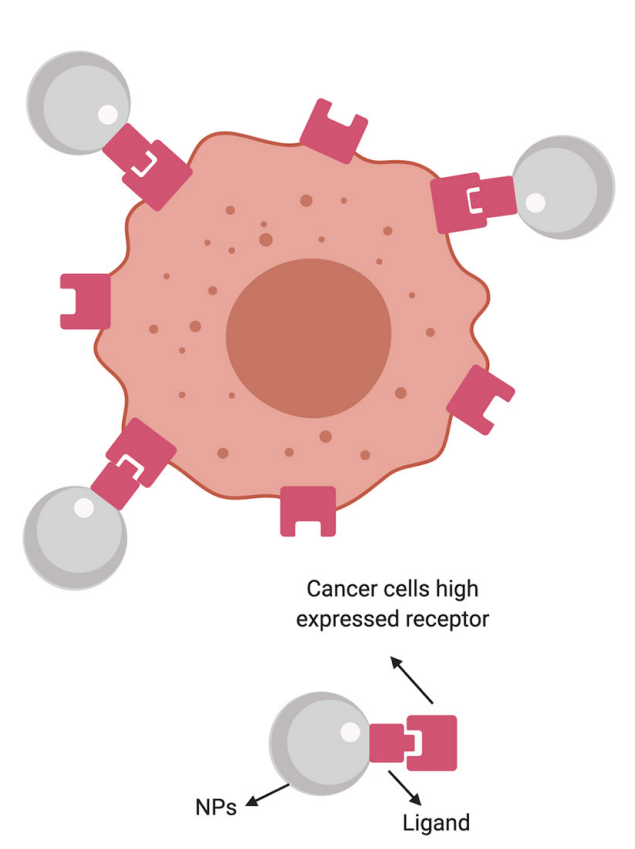

FIGURE 1 | Active and passive uptake of nanoparticles. NPs, Nanoparticles; EPR, Enhanced permeability retention (Created with BioRender.com).

useful to bind biological molecules. For silica NPs, the most used linkers are aminosilanes that introduce an amino group on the NPs surface for the next bio-conjugation (Jung et al., 2012; Rea et al., 2014). Noble metals, like gold, can be functionalized by using crosslinkers with $-\mathrm{SH}$ or $-\mathrm{NH}_{2}$ groups able to react with the metal and to produce a covalent bond. These bifunctional linkers, such as thio-carboxylic acids, have at the other end functional groups to use for binding ligands (Banihashem et al., 2020). Metal oxides can be easily modified by using a ligand exchange strategy based on the substitution of the original surfaces with functional groups such as diol, amine, carboxylic acid, and thiol useful for the next steps (Korpany et al., 2016). The carbon-based nanomaterials contain a significant fraction of $s p^{2}$ hybridized carbon atoms that can be exploited to generate functional groups. Through the oxidation it's possible to generate $-\mathrm{COOH},-\mathrm{OH}$, and $-\mathrm{C}=\mathrm{O}$ on the NPs surface (Chen et al., 2016); through halogenation, it's possible to obtained halogenated carbon that can be further modified, for example by reaction with the amine group (Poh et al., 2013); through cycloaddition it's possible to insert different type of functional groups (Kiang Chua and Pumera, 2013). Table 1 summarizes types of nanomaterials, their chemical groups and/or composition, and the suitable compounds or processes that can be used for surface modification by using crosslinkers.
TABLE 1 | Resume of the most common strategies used to modify NPs surface related to the nanomaterials.

\begin{tabular}{lcc}
\hline Material & $\begin{array}{c}\text { Usable functional/chemical } \\
\text { groups }\end{array}$ & $\begin{array}{c}\text { Example of chemical } \\
\text { compounds/ } \\
\text { processes suitable for } \\
\text { surface modification }\end{array}$ \\
\hline Silica & $-\mathrm{SiOH}$ & $\mathrm{X}-\mathrm{Si}\left(\mathrm{OC}_{2} \mathrm{H}_{5}\right)_{3}$ \\
Noble metals & $-\mathrm{Au} ;-\mathrm{Ag}$ (plasmonic metals) & $\mathrm{X}-\mathrm{SH}, \mathrm{X}-\mathrm{NH}_{2}$ \\
Metal oxide & $\mathrm{MO}$ & $\mathrm{X}-\mathrm{COOH} ; \mathrm{X}-(\mathrm{OH})_{\mathrm{n}} ; \mathrm{X}-\mathrm{NH}_{2}$ \\
& & $\begin{array}{c}\text { (adsorption) } \\
\text { Carbon based }\end{array}$ \\
& $\mathrm{sp}^{2}$ hybridize carbon & Oxidation; halogenation, \\
& & cycloaddition ...
\end{tabular}

The modification of the NPs surface can be achieved using two different approaches: non-covalent and covalent conjugation. The non-covalent strategy is based on a large number of weak interactions (electrostatic, ionic, van der Walls and hydrophobic interactions, absorption, hydrogen bonds) and it is specially used with metallic and silica NPs (Cheng et al., 2011; Nell et al., 2016; Yue et al., 2019). Non-covalent bonds have the advantage of being relatively simple and do not affect the structure of the used molecules and their interaction with biological targets. Conversely, non-covalent modifications can be easily 
influenced by different variables, such as $\mathrm{pH}$ and ionic strength (Nobs et al., 2004).

The covalent bond strategy can be obtained by using many alternative approaches, depending on the composition of the NPs (Abánades Lázaro et al., 2017; Oriana et al., 2018; Sakaguchi et al., 2019). Moreover, this strategy allows modifications at several levels using sequential functionalization (Gong et al., 2015; Tian et al., 2015; Świetek et al., 2019). This methodology can be exploited to achieve structures with multiple functions (Chen and He, 2015; Luo et al., 2016), such as diagnosis and therapy to implement the theranostic approach (Shen et al., 2017; Jung et al., 2018). Usually, the covalent bond of ligands to the NPs surface can be achieved using various linker molecules. An example is PEG, that can be synthesized with specific functional groups at the ends and used as homobifunctional or heterobifunctional linkers to perform a wide range of functionalization processes. Pagels et al. (2020) showed how the production of specific heterobifunctional PEG molecules is still an active research field and how this molecule can be very useful to design efficient nano-platforms for medical applications. Thanks to its polymeric nature, PEG can be also used as a spacer for high molecular weight molecules in order to space them across the surface of the NPs and to reduce steric hindrance of bonded ligands, allowing bioconjugation at high density (Chen S. et al., 2017). Generally, non-covalent interactions are used to load nanoparticles with molecules that must be released in target cells, such as drugs or RNAi, while covalent bonds are employed to bind ligands useful to achieve targeting and/or to reduce he toxicity of NPs. Recently, the use of sensitive bonds, such as $\mathrm{pH}$-sensitivity or heat-sensitivity, to develop nanoplatforms for a controlled drug-release has been widely explored (Tai et al., 2009; Lv et al., 2016; Deirram et al., 2019). In particular, the tumor microenvironment is very acidic when compared to the normal microenvironment. $\mathrm{pH}$-sensitive nano-platforms can been designed for controlled drug release specifically triggered by the acidity of the tumor environment. In a recent work, a cationic polymer PBAE $\mathrm{pH}$-sensitive was used to cover liposome NPs loaded with doxorubicin. Furthermore, the NPs surface was modified with hyaluronic acid (HA) to perform active targeting via CD44. In vivo experiments confirmed the results obtained in vitro, showing that the DOX-loaded NPs inhibited the growth of tumor more efficiently compared to free drug and also reduced side-effects (Men et al., 2020). Another example of $\mathrm{pH}$-sensitive NPs is reported by Taleb et al. (2019). In this work, mesoporous silicon nanoparticles were functionalized with amine conjugated phenylboronic acid linked to dopamine with a $\mathrm{pH}$-sensitive covalent bond. In a weakly acidic environment, as like the tumor environment, the nanoparticles released dopamine owing to the hydrolysis of boronic-ester bond between the two molecules. This intelligent release resulted in an inhibition of vascular endothelial cell migration and tubule formation.

\section{Evaluation of NPs Uptake}

Several methods have been used to evaluate the internalization of nanoparticles in a specific cellular context that can be distinguished as label-free and label-based techniques. Among the label free methods, the most commonly used are transmission electron microscopy (TEM), scansion electron microscopy (SEM), and Raman microscopy. These procedures, unlike labelbased ones, have the advantage of not requiring the use of fluorophores that could affect the NPs size or chemical properties. Furthermore, using labeled-NPs complicates the discrimination of internalized NPs or those attached to the cell membrane. Conversely, TEM and SEM imaging, despite offering highresolution down to the cellular organelle scale, are relatively expensive and time-consuming. Furthermore, TEM and SEM, unlike Raman microscopy, are destructive imaging approaches.

TEM analysis is widely used to study nanoparticle uptake and cellular localization. Rio-Echevarria et al. (2019) showed a better affinity of the epoxy-coated $\mathrm{SiO}_{2}$ nanoparticles for the cell membrane, compared to bare NPs, in A549 cells and human monocytes. Furthermore, TEM allowed to identify the nanoparticles in endosomes. Youhannayee et al. (2019) used TEM analysis to evaluate the uptake of bare and APTEScoated iron oxide nanoparticles in PC3 (prostate cancer epithelial cell) and BPH1 (benign prostate hyperplastic epithelia cell) cell lines. Results showed that PC3 cells internalized coated particles with higher efficiency than BPH1 cells. Boyoglu et al. (2013) used SEM analysis to correlate the size of gold nanoparticles with their cellular localization in HEp-2 cells. Results showed that the presence of nanoparticles in the cytosol and nucleus was simply based on their sizes, regardless of the incubation time.

Among label-free techniques, Raman microscopy presents several advantages useful to study nanoparticles uptake. Compared to SEM and TEM analysis, Raman microscopy requires minimum sample preparation and allows in vitro and in vivo cellular imaging. This methodology was used by Managò et al. (2018) to evaluate the internalization kinetics and intracellular localization of diatomite-based nanoparticles in a lung epidermoid carcinoma cell line. The results indicated the presence of NPs up to $72 \mathrm{~h}$, without damage to cell viability or morphology. Raman microscopy has also been used to study the uptake of metal-based nanoparticles. Using this technique, Chaves et al. (2017) explored the cellular uptake of iron oxide nanoparticles in breast cancer cells. The NPs were totally internalized in cells, displaying a cytoplasmic localization with a direction toward the nucleus after $24 \mathrm{~h}$ of incubation.

Label-based techniques include methods that exploit a fluorescent signal emitted by the nanoparticles. This signal can be attributed to an intrinsic property of the NPs (Suzuki et al., 2007; Chen et al., 2014) or to the use of a fluorophore added to the nanoparticles. This modification can be obtained adding the fluorescent tag inside the NPs structure during synthesis or binding the tag to the NPs surface.

The use of this approach to study NPs cellular uptake has several advantages like the ease of use, no need or simple specimen preparation, possibility to analyze live-cells and to perform time-lapse acquisitions. However, fluorescence methods do not allow a quantitative analysis, but only comparison between different experimental conditions (semi-quantitative analysis). This is due to the fact that the signal is not absolute because 
its intensity depends on the excitation source, the number of fluorophores per NP, the quantum yield of fluorophores or the NP itself, and the sensitivity of the detector (Drasler et al., 2017).

The most used label-based techniques to study NPs cellular uptake are confocal fluorescent microscopy (CFM) and flow cytometry (FC).

Owing to very high resolution, contrast and penetration depth, CFM allows the detection of very low amounts of NPs and to localize them to cellular compartments. Costanzo et al. (2019) used CFM to study the uptake of various types of NPs [liposomes, mesoporous silica NPs, poly(lactide-co-glycolide) NPs, and nanohydrogels] in myoblasts with a high proliferative rate and in myotubes characterized by a low proliferative rate, to correlate proliferative rate with NPs uptake. The results showed that there was a lower uptake in myotubes compared to myoblasts and the inability to penetrate in nucleus by all analyzed NPs in both cell types. Silvestri et al. (2019) evaluated melanin-silica hybrid nanoparticles uptake in two pancreatic cancer cell lines where NPs appeared as punctate small vesicles, indicating an endocytic mechanism of internalization.

The use of flow cytometry to study NPs uptake is widely used, despite the impossibility of discriminating NPs attached on cellular surface from the internalized ones. Jochums et al. (2017), using NPs labeled with the fluorescent dye fluorescein isothiocyanate (FITC), evaluated $\mathrm{TiO}_{2}$ NPs uptake in NIH/3T3 and A549 cell lines. The authors observed that NIH/3T3 cells internalized the $\mathrm{TiO}_{2}$ NPs more efficiently than A549 cells, confirming the importance of the cell type in the uptake behavior. Flow cytometry can also be used to investigate the internalization pathway of the nanoparticles. Gao et al. (2013) investigated the uptake pathway of bare and IL13-modified nanoparticles using several specific endocytosis inhibitors and flow cytometry. Their results showed that bare NPs were internalized by macropinocytosis while IL13-modified NPs were internalized by a clathrin-mediated pathway, typical of a receptor-mediated uptake.

\section{NPs Biocompatibility Evaluation}

To study NPs biocompatibility, there are several aspects, summarized in Figure 2 that can be evaluated: cell viability (Figure 2A), cytotoxicity (Figure 2B), proliferation (Figure 2C), apoptosis/necrosis (Figure 2D), cellular morphology alteration, oxidative stress (Figure 2E), inflammatory response, and hemotoxicity (Figure 2F). Using different methodologies exploiting commercial kits and/or protocols adapted to the type of analysis it is possible to assess these aspects. Some of the most useful markers/pathways are summarized in Table 2.

\section{NPs SURFACE MODIFICATION TO ENHANCE BIOCOMPATIBILITY AND UPTAKE}

The physiochemical properties of NPs, like shape, size, charge, material and surface chemical groups, influence their toxicity and uptake efficiency. Some of these, such as surface charge and chemical groups, can be easily modified by surface modification.

\section{Biocompatibility and Immune Escape}

The functionalization of the NPs surface to enhance biocompatibility can be exploited by using different molecules; among these PEG is one of the most used for in vitro and in vivo applications. Kostiv et al. (2017) showed how the addition of PEG on the surface of $\mathrm{Fe}_{3} \mathrm{O}_{4}$ and $\mathrm{SiO}_{2}$ NPs increased the biocompatibility when PEGylated NPs were used at high concentrations $(200 \mu \mathrm{g} / \mathrm{mL})$ with murine neural stem cells, unlike bare $\mathrm{Fe}_{3} \mathrm{O}_{4} \& \mathrm{SiO}_{2}$ that caused a viability reduction of about $50 \%$ already at a dose of $20 \mu \mathrm{g} / \mathrm{mL}$. This study is a clear example of the high convenient properties of PEG to increase NPs biocompatibility. Furthermore, the presence of PEG on the NPs surface also improves the hemocompatibility, as observed with chromium-doped zinc gallate and diatomite based NPs (Terracciano et al., 2015; Jiang et al., 2019).

To reduce the toxicity of NPs, dextran is a widely used to modify nanoparticles. Dextran is a complex branched polysaccharide usually exploited to modified iron-oxide NPs surface. de Oliveira et al. (2017) showed how the addition of dextran to iron-oxide NPs increased biocompatibility in zebrafish larvae; in particular, the treatment with dextran-coated NPs did not determine any significant mortality or changes in the hatching rate of the larvae. The toxicity of dextran modified ironoxide NPs was also investigated by Balas et al. (2017) on Jurkat cells. The authors observed low toxicity and small effects on membrane integrity up to $72 \mathrm{~h}$ of incubation. The use of dextran with iron-oxide nanoparticles to improve biocompatibility was also studied using primary cells. Wu et al. (2018) demonstrated that dextran-NPs had no significant effects on cell viability and apoptosis on human primary monocytes cells.

A further oligosaccharide generally used to enhance NPs biocompatibility is chitosan, as reported by Shukla et al. (2015) and Peng et al. (2017). Shukla et al. (2015) observed a decrease of toxicity in three different cell lines when chitosan-NPs were compared to iron-oxide NPs. Peng et al. (2017) used chitosan to modify silver NPs. Results showed that chitosan-coated silver nanoparticles had higher biocompatibility when compared with silver nanoparticles without surface modification in human fibroblast cells.

A more complex NPs surface modification as way to enhance biocompatibility, stability and dispersity was been reported by Han et al. (2016). The study demonstrated that encapsulation of mesoporous silica NPs using a lipid bilayer is a useful way to improve biocompatibility and hemocompatibility.

Besides the increase of biocompatibility, NPs surface modification is a very important tool for the modulation of the body's immune response against the particles (Qie et al., 2016; Boraschi et al., 2017; Visalakshan et al., 2019). NPs, after the injection in blood flow, interact with a lot of aspecific proteins like opsonin, complement proteins, immunoglobulins, fibronectin, and apolipoproteins (protein corona) and this interaction can modify NPs behavior and can trigger an immune response (Barbero et al., 2017). The NPs surface modification can be exploited to promote their escape from the immune system 


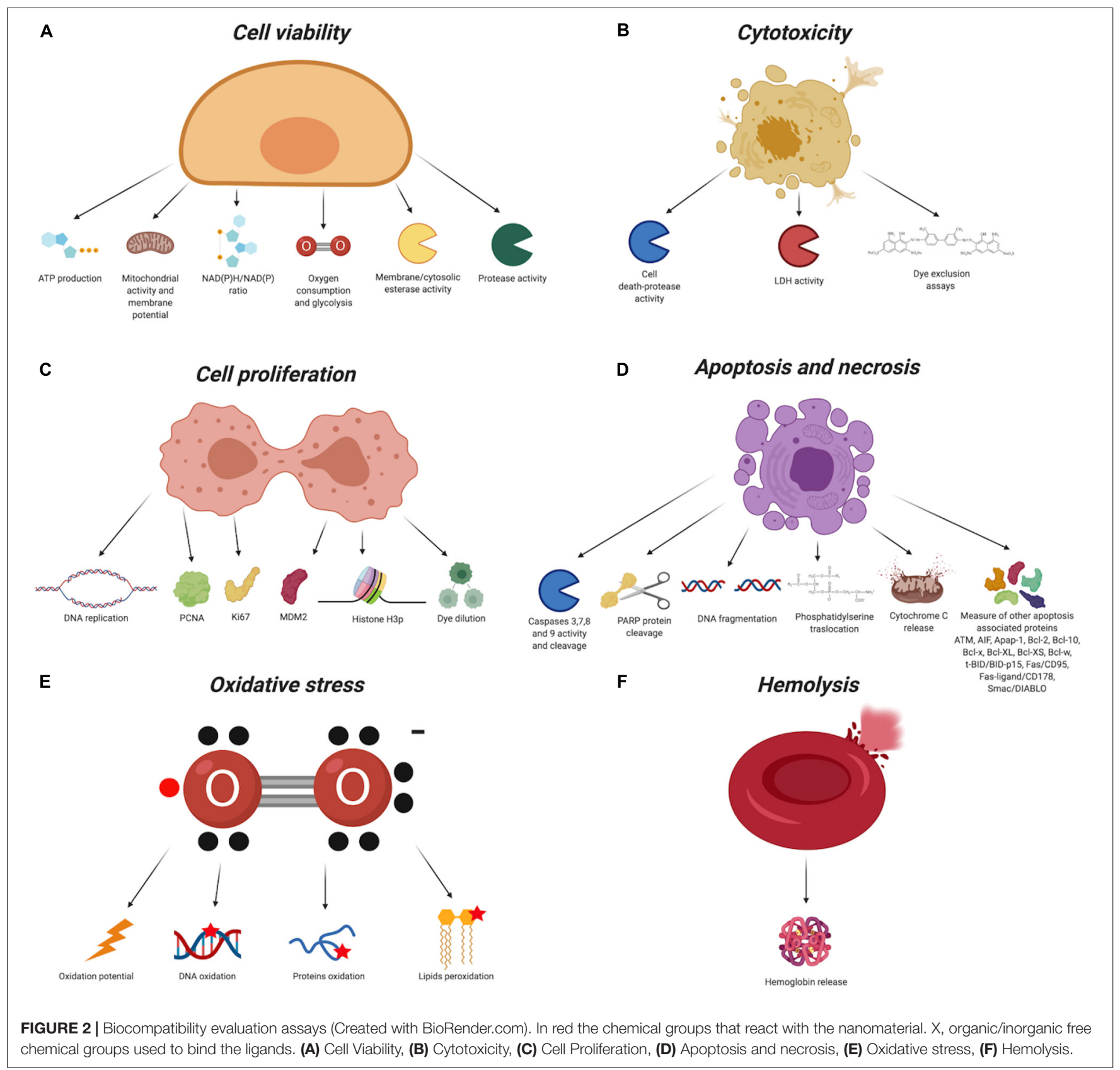

and to increase their half-life in blood by reducing the clearance due to macrophages of the mononuclear phagocyte system (MPS). Conversely, in the next-generation vaccines, the NPs surface modification can trigger the immune response toward a specific antigen (Ahmad S. et al., 2019; Cappellano et al., 2019; Gu et al., 2019).

Escape from the immune system can be obtained through the modification of NPs surface with different types of molecules that make NPs "invisible" to the immune system cells. For this purpose, the most used compounds are hydrophilic polymers that bind water molecules producing a shield on NPs surface. This layer of water reduces the interaction with opsonin and/or macrophages receptors (Pinzaru et al., 2018). This strategy can increase NPs circulation time and can reduce the clearance (Abdollah et al., 2018).

\section{Uptake}

It is well known that the cellular uptake of NPs is influenced by the physicochemical properties of NPs, such as its composition, size, shape, surface charge, surface functionalization, and surface hydrophobicity/hydrophilicity. When nanoparticles interact with the constituents of the plasma membrane, they are mainly taken up by cells by endocytosis, which is commonly classified in phagocytosis (macrophages) and pinocytosis (all cellular types). The latter can be distinguished in clathrin-dependent endocytosis, caveolae-dependent endocytosis, macropinocytosis, 
TABLE 2 | Biocompatibility evaluation assays used to asses NPs toxicity.

\begin{tabular}{|c|c|c|c|c|}
\hline & Description & Detection method & Info & References \\
\hline \multirow[t]{6}{*}{$\begin{array}{l}\text { Cell viability } \\
\text { (evaluation of cells health state) }\end{array}$} & Measure of ATP concentration & $\begin{array}{l}\text { Fluorescence, colorimetry, } \\
\text { luminescence }\end{array}$ & $\begin{array}{l}\text { The ATP assay showed very high versatility and ease-to-use in fact } \\
\text { it is used for several different types of nanoparticles like high-density } \\
\text { lipoprotein, gold, silver and silica. Furthermore, the use of } \\
\text { luminescence as ATP quantification method doesn't show } \\
\text { interference with fluorescence/adsorption of nanoparticles }\end{array}$ & $\begin{array}{l}\text { Vetten et al., 2013; Cao et al., } \\
\text { 2017; Suganuma et al., 2017; } \\
\text { Fehaid and Taniguchi, 2019; } \\
\text { Silvestri et al., 2019; Wang } \\
\text { et al., } 2019\end{array}$ \\
\hline & Evaluation of $\mathrm{NAD}^{+} / \mathrm{NADH}$ ratio & $\begin{array}{l}\text { Luminescence, colorimetry, } \\
\text { fluorescence }\end{array}$ & $\begin{array}{l}\mathrm{NAD}^{+} \text {and NADH are very important molecules for a lot of cellular } \\
\text { processes and their levels are related to cell health. The disponible } \\
\text { luminescence-based assays can avoid fluorescence/adsorption of } \\
\text { NPs }\end{array}$ & $\begin{array}{l}\text { Da Veiga Moreira et al., 2016; } \\
\text { Patgiri et al., } 2020\end{array}$ \\
\hline & $\begin{array}{l}\text { Measure of mitochondrial } \\
\text { membrane potential }(\Delta \Psi \mathrm{m})\end{array}$ & Fluorescence & $\begin{array}{l}5,5^{\prime}, 6,6^{\prime} \text {-Tetrachloro- } 1,1^{\prime}, 3,3^{\prime} \text {-tetraethyl-imidacarbocyanine iodide } \\
\text { (JC-1) dye accumulates in the mitochondrial membrane depending } \\
\text { on membrane potential. The high potential of the inner } \\
\text { mitochondrial membrane induces the formation of the dye } \\
\text { aggregates. Free dye and aggregates have different fluorescence } \\
\text { properties. This shift is used to analyze mitochondria membrane } \\
\text { potential }\end{array}$ & $\begin{array}{l}\text { Chen C. et al., 2017; Popov } \\
\text { et al., } 2020\end{array}$ \\
\hline & $\begin{array}{l}\text { Evaluation of } \\
\text { membrane/cytosolic esterase } \\
\text { activity }\end{array}$ & Fluorescence & $\begin{array}{l}\text { Membrane esterase evaluation to study cell viability is widely used } \\
\text { to assess NPs toxicity both with flow cytometry and fluorescence } \\
\text { microscopy analysis to obtain semi-quantitive and qualitative data, } \\
\text { respectively }\end{array}$ & $\begin{array}{l}\text { Bancos et al., 2012; Grudzinski } \\
\text { et al., 2013; Singh and } \\
\text { Lamprecht, 2016; } \\
\text { Hernandez-Delgadillo et al., } \\
\text { 2018; Silvestri et al., } 2019\end{array}$ \\
\hline & $\begin{array}{l}\text { Measure of oxygen } \\
\text { consumption and glycolysis }\end{array}$ & Fluorescence, Luminescence & $\begin{array}{l}\text { The evaluation of extracellular oxygen consumption rates }(\mathrm{OCR}) \text { is } \\
\text { directly related to cell health and mitochondria activity. Furthermore, } \\
\text { the evaluation of L-lactate produced by glycolysis is widely used to } \\
\text { evaluate cellular health state }\end{array}$ & $\begin{array}{l}\text { Luo et al., 2015; Grahovac } \\
\text { et al., 2019; Yun et al., 2019; } \\
\text { Zhu et al., 2019; Adeyemi et al., } \\
2020\end{array}$ \\
\hline & $\begin{array}{l}\text { Evaluation of live-cell protease } \\
\text { activity }\end{array}$ & Fluorescence & $\begin{array}{l}\text { The live-cell protease activity is limited to intact cells and it is } \\
\text { evaluated by using a fluorogenic cell-permeant peptide as substrate } \\
\text { (Gly-Phe-AFC). It is interesting that live-cell proteases activity } \\
\text { decreases when plasmatic membrane loses its integrity and the } \\
\text { enzymes are released in culture medium. This feature can help to } \\
\text { discriminate alive cells from dead cells and to reduce false positives }\end{array}$ & $\begin{array}{l}\text { Amin et al., 2017; Zhang et al., } \\
2020\end{array}$ \\
\hline \multirow[t]{3}{*}{$\begin{array}{l}\text { Cytotoxicity } \\
\text { (evaluation of dead cells) }\end{array}$} & $\begin{array}{l}\text { Membrane damage evaluation } \\
\text { by dye exclusion }\end{array}$ & Colorimetry & $\begin{array}{l}\text { The evaluation of membrane integrity alteration assessed with dyes } \\
\text { (usually Trypan Blu and Erythrosine B) is easy and cheap, but in dye } \\
\text { exclusion cytotoxicity assays (i) survive live cells can continue to } \\
\text { proliferate and (ii) some dead cells can't be revealed because they } \\
\text { may undergo to an early disintegration }\end{array}$ & $\begin{array}{l}\text { Bejjani et al., 2005; Karlsson } \\
\text { et al., 2008, 2013; Fakhimikabir } \\
\text { et al., } 2018\end{array}$ \\
\hline & $\begin{array}{l}\text { Activity evaluation of released } \\
\text { lactate dehydrogenase }\end{array}$ & $\begin{array}{l}\text { Colorimetry, Fluorescence, } \\
\text { Luminescence }\end{array}$ & $\begin{array}{l}\text { The release of lactate dehydrogenase from cells is one of the most } \\
\text { useful marker of cell death. NPs could interfere with enzymatic } \\
\text { activity and/or with colorimetric assays }\end{array}$ & $\begin{array}{l}\text { Forest et al., 2016; Chen C. } \\
\text { et al., 2017; Gea et al., 2019; } \\
\text { Hu et al., } 2019\end{array}$ \\
\hline & & & & (Continued) \\
\hline
\end{tabular}


TABLE 2 | Continued

\begin{tabular}{|c|c|c|c|c|}
\hline & Description & Detection method & Info & References \\
\hline & $\begin{array}{l}\text { Activity evaluation of cell-death } \\
\text { related proteases }\end{array}$ & Fluorescence, Luminescence & $\begin{array}{l}\text { Cell death-proteases release assay estimates the activity of the } \\
\text { intracellular enzymes when they are released after membrane } \\
\text { damage. These cell-death proteases have high activity on specific } \\
\text { target sequences (like Ala-Ala-Phe-R), different from the other } \\
\text { intracellular proteases (like Gly-Phe-R) and for this reason the assay } \\
\text { is very specific. Furthermore, the possibility to perform } \\
\text { luminescence assay can reduce NPs interference }\end{array}$ & $\begin{array}{l}\text { Gonnissen et al., 2016; Iglesias } \\
\text { et al., 2017; Zhang et al., 2017; } \\
\text { Gurunathan et al., } 2018\end{array}$ \\
\hline \multirow[t]{6}{*}{$\begin{array}{l}\text { Cell proliferation } \\
\text { (evaluation of mitotic rate) }\end{array}$} & Evaluation of DNA synthesis & $\begin{array}{l}\text { Fluorescence, Colorimetry, } \\
\text { Luminescence }\end{array}$ & $\begin{array}{l}\text { The evaluation of cell proliferation through DNA synthesis is } \\
\text { performed by incorporation of nucleoside-analog like } \\
5 \text {-bromo-2O-deoxyuridine (BrdU) in DNA. This simple assay is } \\
\text { widely used to assess cell proliferation and genotoxicity in presence } \\
\text { of different nanomaterials. Furthermore, BrdU assay can be } \\
\text { performed both in vitro and in vivo }\end{array}$ & $\begin{array}{l}\text { Ruizendaal et al., 2009; } \\
\text { Hernández-Ortiz et al., 2012; } \\
\text { Al-Qubaisi et al., 2013b; Chen } \\
\text { M. et al., 2019; Kutwin et al., } \\
2019\end{array}$ \\
\hline & Dye dilution & Fluorescence & $\begin{array}{l}\text { During cell proliferation for each generation the amount of dye in } \\
\text { each cell is shared between two cells. The cell proliferation can be } \\
\text { monitored by analysis of dye fluorescence reduction }\end{array}$ & \\
\hline & $\begin{array}{l}\text { Protein cell nuclear antigen } \\
\text { activation (PCNA) }\end{array}$ & $\begin{array}{l}\text { Chemiluminescence, } \\
\text { Fluorescence, Colorimetry }\end{array}$ & $\begin{array}{l}\text { PCNA is a DNA clamp essential for DNA replication in eukaryotic } \\
\text { cells. Its concentration increases during cell proliferation. PCNA has } \\
\text { a lifetime of about } 20 \mathrm{~h} \text { and for this reason it could be detected also } \\
\text { in non-proliferative cells, causing wrong data about cell proliferation }\end{array}$ & $\begin{array}{l}\text { Khdair et al., 2010; AshaRani } \\
\text { et al., 2012; Chairuangkitti } \\
\text { et al., 2013; Li Q. et al., 2018; } \\
\text { Kutwin et al., } 2019\end{array}$ \\
\hline & Ki-67 activation & $\begin{array}{l}\text { Chemiluminescence, } \\
\text { Fluorescence, Colorimetry }\end{array}$ & $\begin{array}{l}\text { Ki- } 67 \text { protein concentration increases in nucleus during cell } \\
\text { progression in S phase. Ki- } 67 \text { that is present in all cell cycle steps } \\
\text { except in G0 state has a half-life of about } 36 \mathrm{~h} \text { and could be still } \\
\text { detected in the first phase of quiescence }\end{array}$ & $\begin{array}{l}\text { Ludwig et al., 2017; Marino } \\
\text { et al., } 2018\end{array}$ \\
\hline & $\begin{array}{l}\text { Minichromosome maintenance } \\
\text { protein } 2 \text { (MCM-2) }\end{array}$ & $\begin{array}{l}\text { Chemiluminescence, } \\
\text { Fluorescence, Colorimetry }\end{array}$ & $\begin{array}{l}\text { MCM2 is a protein involved in the beginning of DNA replication } \\
\text { (pre-replication complex) and cell proliferation. MCM2 is highly } \\
\text { expressed in early G1, low expressed in S, G2, and M phases, and } \\
\text { it is totally absent in G0. Furthermore, MCM2 shows distinct cellular } \\
\text { localization in cycling cells and this pattern can be used to evaluate } \\
\text { cellular proliferation }\end{array}$ & Yang et al., 2010 \\
\hline & Phosphohistone H3 (PPH3) & $\begin{array}{l}\text { Chemiluminescence, } \\
\text { Fluorescence, Colorimetry }\end{array}$ & $\begin{array}{l}\text { Histone-3 is extensively phosphorylated (serine-10 and serine-28) } \\
\text { during mitosis and it is widely used to study cell proliferation }\end{array}$ & $\begin{array}{l}\text { Duong Le et al., 2016; } \\
\text { Surapaneni et al., 2018; Tang } \\
\text { et al., 2018; Brzóska et al., } \\
2019\end{array}$ \\
\hline
\end{tabular}




\section{Apoptosis and necrosis}

(evaluation of

apoptotic/necrotic cells)
Evaluation of

phosphatidylserine

translocation

Measure of nick breaks in DNA

Fluorescence, Colorimetry

Evaluation of PARP protein cleavage

Evaluation of caspases and their cleavage

Colorimetry,
Detection method

Fluorescence

One of the most used molecules to study DNA content is propidium odide. This molecule has fluorescent excitation maximum at

$495 \mathrm{~nm}$ and emission maximum at $630 \mathrm{~nm}$. When PI binds DNA its

quantum yield increases of about 20-30 folds and a significative fluorescence red shift $(535 / 615 \mathrm{~nm})$ is observed. Pl used at low concentrations $(<50 \mu \mathrm{g} / \mathrm{ml})$ cannot pass through the biological membranes of healthy cells but can penetrate into damaged cells like necrotic or late apoptotic cells, allowing their identification. Furthermore, the use of a permeabilizing that allows PI entry in al cells makes possible to evaluate apoptotic cells by studying cell cycle pattern (due to DNA fragmentation, apoptotic cells have lower DNA content compared to healthy cells)

To discriminate necrotic cells from apoptotic ones an additiona staining is necessary. During early apoptosis process, translocation of phosphatidylserine (PS) from the inner to the outer side (extracellular side) of the plasma membrane can be detected by using Annexin $V$ protein conjugated with several different fluorescent dyes.

\section{Propidium lodide Annexin V Type of cell}

Negative Negative Healthy cell

Negative Positive Early apoptotic cell

Positive Negative Necrotic cells

Positive Positive Late apoptotic cells

The most used assay to evaluate the fragmentation of nuclear DNA in consequence of apoptosis is the TUNEL assay. This assay is based on the use of an enzyme (Terminal Deoxynucleotidyl Transferase) that adds dUTP to the 3'-OH DNA ends. The use of labeled dUTP (with fluorescent or chromogenic dyes) can allow the identification and the quantification of DNA fragments by using microscopy or flow cytometry

Poly-ADP-ribose polymerase (PARP) is widely used to assess apoptosis. In apoptotic cells PARP is a substrate for caspase-3 enzyme. PARP protein $(116 \mathrm{kDa}$ ) and its cleavage by caspace-3 in apoptotic events (which produces an $85 \mathrm{kDa}$ fragment) is a useful marker to evaluate apoptosis

Fluorescence, Luminescence,

Chemiluminescence
References

Kumar et al., 2015; Li et al., 2019b: Silvestri et al., 2019; Yang et al., 2019a

Kim et al., 2019; Xiao et al., 2019; Zhu et al., 2019; Adeyemi et al., 2020; Ding et al., 2020; Elkeiy et al., 2020

Popovtzer et al., 2016; Yu et al., 2017; Phuong et al. 2018; Ding et al., 2020

Kang et al., 2009; Zhang et al. 2013; Al-Shakarchi et al., 2018; Wang et al., 2018; Ahmad N.

et al., 2019

Baharara et al., 2016; Al-Shakarchi et al., 2018; Blanco et al., 2018; Kalaiaras et al., 2018; Ahamed et al., 2019; Kang et al., 2009; Baharara et al., 2016; Banerjee et al., 2017; Zhang et al., 2017;
Kalaiarasi et al., 2018 synthesized how pro-enzymes and activated during apoptosis by proteolytic cleavage. There are several different ways to evaluate the active enzymes based on the use of specific antibodies: flow cytometry, western blot or immunohistochemistry. Furthermore, it is possible to evaluate caspases enzymatic activity in cells by using specific substrates trough fluorescence, colorimetry or luminescence 
TABLE 2 | Continued

\begin{tabular}{l} 
Description \\
\hline Cytochrome C release \\
\\
Measure of other apoptosis associated \\
proteins: ATM, AIF, Apap-1, Bcl-2, Bcl-10, \\
Bcl-x, Bcl-XL, Bcl-XS, Bcl-w, t-BID/BID-p15, \\
Fas/CD95, Fas-ligand/CD178, Smac/DIABLO, \\
p53.
\end{tabular}

Detection method

Info

References

Chemiluminescence,

Fluorescence, Colorimetry

The enrichment of cytochrome $\mathrm{C}$ in cytoplasm and its decrease in

mitochondria can be detected by several techniques, like western blot or immunofluorescence

\section{Chemiluminescence,}

There are a lot of proteins involved in apoptosis that can be

Fluorescence, Colorimetry

detected by using specific antibodies

Al-Qubaisi

et al., 2013a

Plackal

Adimuriyil

George et al.

2018

Spectrophotometric and naked eye

Oxidative stress General oxidative stress

Fluorescence, Luminescence

Hemolysis can be easily evaluated by measuring hemoglobin released from red blood cells by naked eye evaluation (qualitative) or by spectrophotometric analysis at $577 \mathrm{~nm}$ (quantitative)

General oxidative stress assays are based on cell-permeable molecules with low or not fluorescence in a reduced state. When these molecules go inside cells they will be oxidized and become fluorescent proportionally to the oxidative potential in cells. In the past two molecules were widely used to evaluate general oxidative stress: 2',7'-dichlorodihydrofluorescein diacetate $\left(\mathrm{H}_{2} \mathrm{DCFDA}\right)$ and dihydroethidium (DHE). Due to several limitations of both molecules like need to serum-free media, low stability, incompatibility with PFA fixing, GFP and RFP and detergents, innovative

fluorogenic/luminogenic oxidative stress reagents are product to evaluate oxidative stress

DNA oxidation

Colorimetric (ELISA)

For the evaluation of DNA oxidative stress, analysis of 8-hydroxydeoxyguanosine (8-OHdG) in DNA can be performed. $8-\mathrm{OHdG}$ is a DNA modified base produced by hydroxyl radical attack of guanine in oxidative stress conditions. The $8-\mathrm{OHdG}$ evaluation assay is usually used in combination with others assay to evaluate DNA integrity, like COMET and TUNEL assays.

Carbonyl groups (aldehydes and ketones) are usually specific

Chemiluminescence, markers of proteins oxidation. The amount of carbonyl groups can be detected by using 2,4-Dinitrophenylhydrazine (DNPH) that reacting with the carbonyl groups on proteins produces a DNP-tag detectable by western blot or ELISA. Furthermore, there are also DNPH-modified molecules that can be detected by colorimetric or fluorescent methods

Lipid peroxidation

Colorimetry (ELISA), Fluorescence

During oxidative stress, lipid peroxidation produces reactive aldehydes such as the mutagenic compound malondialdehyde (MDA) and the toxic compound 4-hydroxynonenal (4-HNE). MDA molecule is the most used marker to evaluate lipid peroxidation, because it reacts with thiobarbituric acid (TBA) to produce an MDA-TBA adduct that can be easily detected by colorimetric, fluorimetric and ELISA assays

Sanità et al., 2020

Aranda et al., 2013; Ghosh et al., 2016; Ahamed et al., 2019

Ghosh et al., 2016; Kinoda et al., 2016; $\mathrm{Ng}$ et al., 2017

Arya et al., 2016; Jayaram et al., 2017

Gaharwar et al. 2017; Ahamed et al., 2019

${ }^{a}$ The use of tetrazolium salt based assays (like MTT, MTS,S and WST-1) or crystal violet can be affected by NPs absorbance properties (Almutary and Sanderson, 2016) resulting in high toxicity overestimation, for this reason they are not added to this table. 
and clathrin, and caveolae-independent endocytosis. The modification of the physicochemical properties of NPs surface can be exploited to enhance cellular uptake.

\section{Passive Uptake}

PEG, usually tested to enhance biocompatibility, can also be explored to increase NPs uptake. The PEG monomer is about $0.35 \mathrm{~nm}$ in length with a molecular weight of about $2 \mathrm{kDa}$, and can be synthesized at different lengths. This molecule reduces aggregation and increases NPs stability in biological fluids (Desai et al., 2016; Harrison et al., 2016). Furthermore, PEGylation of NPs determines a decrease of the interaction with not-specific proteins resulting in a "stealth" effect able to enhance PEG-NPs circulation time and to reduce phagocytosis (Vonarbourg et al., 2006). This increased stability of PEG-NPs is directly related to higher cellular uptake if compared with bare NPs that can aggregate in biological environment and/or to be phagocytized by immune system cells.

As reported by $\mathrm{Cu}$ and Saltzman (2009), the use of PEG can effectively change the behavior of NPs in relation to its delivery in tissues. The addition of PEG of different sizes $(2.5,5$, and $10 \mathrm{kDa}$ ) on poly(lactic-co-glycolic) acid (PLGA) on the NPs surface can enhance particle diffusion by up to 10 -fold into the cervical mucus and the binding to mucin proteins, depending on the PEG density and size. Furthermore, the conjugation with PEG results in a shift in the charge of PLGA NPs, from -45 to $+8 \mathrm{mV}$, with the NPs size increase related to the efficiency of PEG coverage. Cruje and Chithrani (2014) showed that NPs properties can be affected by the length of PEG molecule and by the surface functionalization density (PEG molecules $/ \mathrm{nm}^{2}$ ). In particular, when longer PEG molecules and a high density were used to functionalize gold NPs, a reduction in the nonspecific protein adsorption was observed. However, this kind of modification resulted in a decrease in the uptake of NPs in all cell lines tested.

Other molecules used to modify NPs surface involve changes in the superficial charge. Generally, these consist of amino ending molecules $\left(\mathrm{R}-\mathrm{NH}_{2}\right)$ that at physiological $\mathrm{pH}$ (about 7.4) are positively charged. Rancan et al. (2012) demonstrated how the surface charge of silica nanoparticles $\left(\mathrm{SiO}_{2}\right)$ affects the cellular uptake of NPs in the $\mathrm{HaCaT}$ cell line and in skins explants. Negatively charged $\mathrm{SiO}_{2}$ NPs showed lower uptake levels compared to positive 3-aminopropyl-trimethoxysiliane (APS) modified NPs. Conversely, Liu et al. (2011) reported that polystyrene-modified NPs with $-\mathrm{NH}_{2}$ groups on the surface enhanced toxicity, related to the high reactivity of the amino groups. The higher uptake and toxicity of positively charged NPs, compared to negatively charged NPs, has also been demonstrated by Bannunah et al. (2014) in an intestinal epithelial cell model.

Furthermore, the superficial charge of NPs can be selectively modified to modulate the cellular uptake. Zwitterionic ligands, like carboxybetaines and sulfobetaines, show a variety of the positively and negatively charged groups allowing the modulation of charge densities to optimize solubility and to avoid the interactions of the protein corona, making NPs highly stable in biological fluids. This modification reduces non-targeted uptake and opsonization of modified-NPs, and increases their accumulation in target tissues (e.g. cancer cells) (Breus et al.,
2009; Muro et al., 2010; Zhang et al., 2011). An example of the zwitterionic ligands useful to enhance NPs uptake is reported by Drijvers et al. (2019). In this work, silica coated $\mathrm{CdSe} / \mathrm{CdS}$ quantum dots were biofunctionalized with PEG and with sulfobetaines in order to evaluate the impact of these modifications on the NPs cellular uptake. The authors showed the differences in the cellular internalization and, in particular, they revealed that the uptake of the zwitterionmodified NPs happened more easily compared to PEG-modified NPs in HeLa cells.

In Mosquera et al. (2018) gold-NPs were modified with pyranine (a negatively charged dye) that reduced the NPs uptake. This behavior can be reversed through the addition of a positively charged molecular cage that neutralizes the negative charge of gold NPs and allows cellular uptake. The key role of the surface charge of NPs in cellular uptake efficiency was also demonstrated by Jeon et al. (2018), where the surface of fluorophore-conjugated polystyrene nanoparticles (f-PLNPs) was modified with different types of functional groups (acetyl, zwitterionic, carboxyl) and molecules (guanidinium, polyethylene glycol, sulfonic acid). The nanoparticles were incubated with THP-1 cells (phagocytic) or A549 cells (non-phagocytic). Results showed a NPs superficial charge-dependent uptake by both cell lines; in particular, an increasing trend in internalization was observed in positively charged modified-NPs and this correlation was stronger in the THP-1 cells compared to A549 cells.

Another strategy widely explored to increase NPs uptake is based on the use of cell penetrating peptides (CPPs). These molecules are composed of a specific aminoacidic sequence, usually polycationic or amphipathic structures, that enhance NPs uptake. Asai et al. (2014) used a CPP derived from protamine to modified lipid-based NPs for the efficient delivery of siRNA. This modification enhanced internalization of siRNA in B16F10 cells. Feiner-Gracia et al. (2018) exploited the penetrating capability of Tat peptide to functionalize PLGA NPs surface. They observed that while bare NPs did not enter HeLa cells, when Tat peptide was added (Tat-NPs), cellular uptake was detected.

Due to the importance of enhancing the uptake of NPs, research into alternative molecules that bind on the NPs surface is very active. Yang et al. (2018) reported the use of phosphatidylcholine (PC) modified with different alkyl chain lengths (from C12 to C18), to increase lipid-PLGA hybrid NPs internalization. Even if PC had little effect on NPs stability and physicochemical properties, results showed an enhanced cellular uptake of hybrid nanoparticles in HepG2 or A549 cells. Furthermore, the PC-modified NPs uptake increased proportionately to the length of PC alkyl chain.

\section{Active Uptake}

In recent years, surface modification of NPs was mainly aimed at active targeting and cellular uptake by exploiting the specific interactions of NPs surface ligands with a wide range of receptors overexpressed in cancer cells (Salahpour Anarjan, 2019). The molecules useful to perform NPs active uptake include several main categories, among these the most used are antibodies, small peptides, proteins, aptamers, carbohydrates, and small molecules (Figure 3). During the conjugation process, usually performed by covalent interactions, these molecules are linked 


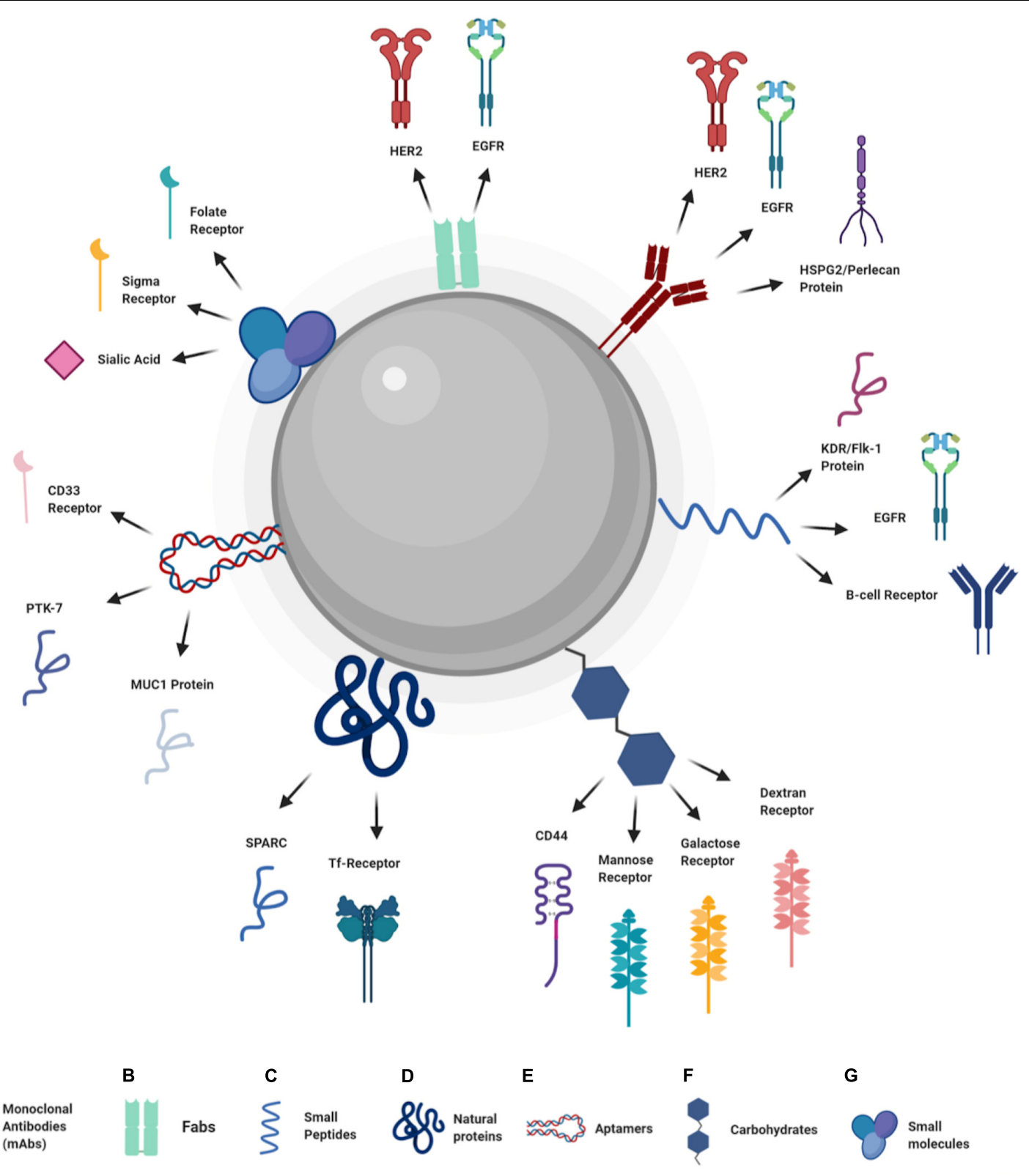

FIGURE 3 | Design of nanoparticles for active uptake (Created with BioRender.com). (A) Monoclonal Antibodies, (B) Fabs, (C) Small Peptides, (D) Natural Proteins, (E) Aptamers, (F) Carbohydrates, (G) Small molecules.

to the NPs surface in order to preserve their ability to bind the target receptors.

Monoclonal antibodies (mAbs) used to perform active uptake of NPs are extensively studied due to their high stability, specificity and binding ability (Figure 3A). Fathian kolahkaj et al. (2019) reported a very efficient uptake of PLGA NPs modified with an anti-HER2 mAb. Uptake evaluation in HER2 positive (MDA-MB-453) and negative (MCF-7 and BT-20) cells demonstrated higher internalization levels in a HER2 positive cell line, compared to the negative ones. Another example related to the use of targeted uptake with the anti-HER2 antibody was reported by Wu et al. (2019). In this work, boron-containing gold NPs were bioconjugated with an anti-HER2 antibody and their uptake was studied both in vitro and in vivo. Results showed an elevated selective uptake in N87 human gastric cancer cells of $\mathrm{mAb}$-gold NPs when compared to bare NPs. In vivo experiments indicated accumulation of mAb-gold NPs in tumor sites and a reduction of non-specific uptake at others anatomical districts. Another receptor widely used to perform active uptake in cancer cells is the epidermal growth factor receptor (EGFR). As reported by McDaid et al. (2019), the functionalization of PLGA NPs surface by using a therapeutic mAb against EGFR (Cetuximab) 
enhanced the NPs uptake in an in vivo model. A further example of mAb modified NPs to improve cellular internalization was reported by Khanna et al. (2019), where PLGA nanoparticles were functionalized with a $\mathrm{mAb}$ against heparan sulfate proteoglycan 2 (HSPG2) protein, a surface receptor highly expressed in triple negative breast cancer (TNBC) that binds growth factors such as VEGF-A and FGF-2, acting as "co-receptor." Even in this study the presence of $\mathrm{mAb}$ on the NPs surface increased specific cellular uptake in Luciferase-expressing MDA-MB-231-LM2 cells.

Antibodies are very useful molecules to enhance specific NPs uptake, but they have high molecular weight (about $150 \mathrm{kDa}$ ), and this could be an issue in bioconjugation process, above all with smaller NPs $(<10 \mathrm{~nm})$. The use of the antibody antigenbinding fragments (Fabs) to perform NPs active uptake is a viable alternative, as reported by Houdaihed et al. (2020) (Figure 3B). To target breast cancer cells, the PEG-PLGA NPs were loaded with paclitaxel and everolimus and the NPs were coated with anti-HER2 and anti-EGFR Fabs. Results showed higher uptake levels in HER2 and EGFR positive cell lines (SKBR3) compared to negative or low EGFR expressing cell lines (MCF-7 and MDAMB- 436).

A viable alternative to the use of antibodies and Fabs to modify NPs surface is represented by peptides that bind with high affinity to specific receptors (Figure $3 \mathrm{C}$ ). Indeed, specific peptides can be obtained by the screening of phage libraries and by the isolation of binding sequences from proteins using three-dimensional (3D) structural analysis. A small peptide (GE11) with high affinity for EGFR was used by Li et al. (2019a) to modify nanomicelle containing evodiamine (GE11-Evo-NPs) in order to enhance drug uptake into cancer cells. Results obtained in vivo showed that GE11-Evo-NPs allow higher evodiamine concentration in tumor after intravenous administration, compared to the drug alone. Furthermore, the accumulation of GE11-Evo-NPs in tumor masses in vivo was higher than Evo-NPs. Another study where a peptide was used to enhance active NPs accumulation is reported by Qian Q. et al. (2019). In this study, hybrid chitosan/poly(N-isopropylacrylamide) NPs functionalized with K237 peptide (that binds KDR/Flk-1 receptor) were described. The modified NPs showed higher uptake in the MDA-MB-231 cell line overexpressing KDR/Flk-1 compared to K237 free NPs and to L929 cells that do not express the KDR/fLK-1 receptor. The use of peptides was also explored to perform a personalized therapy approach. Martucci et al. (2016) showed that the surface functionalization of diatomite-based NPs with an idiotypespecific peptide (Id-peptide), which recognizes hypervariable region of immunoglobulin B-cell receptor, enhanced Id-NPs uptake in specific myeloma cells of threefold compared to nonspecific cells. Furthermore, same results were obtained if a random control peptide was used.

The use of natural proteins that interact with cancer cell receptors has been widely investigated, as reported in several recent studies (Figure 3D). Scheeren et al. (2020) used transferrin (Tf) to functionalize the surface of doxorubicin-loaded PLGA NPs. The interaction between transferrin and Tf receptors (Tf-R), highly expressed in cancer cells, was exploited to enhance uptake and drug release. Results showed that Tf-PLGA@DOX NPs greatly reduced viability of human epithelial cervical cancer cells
HeLa (Tf-R positive), when compared to immortalized HaCaT keratinocytes with low Tf-R expression. Another protein used to perform NPs active delivery is human serum albumin (HSA) that interacts with tumor-associated protein SPARC. Sanità et al. (2020) modified hybrid melanin-silica-silver nanoparticles (MelaSil_Ag) surface using HSA to enhance cellular uptake in breast cancer cells. Results showed that MelaSil_Ag-HSA NPs were mostly internalized by SPARC positive cell line (HS578T) compared to SPARC negative cells (MCF10a).

Furthermore, other molecules are currently being explored to modify NPs surface and to perform active uptake. Among these, aptamers represent a useful molecule since are cheap and easy to synthetize (Figure 3E). Aptamers are short nucleic acid sequences (dsDNA, ssDNA or RNA) with specific 3D structure that can bind a molecular target in cancer cells with high specificity and affinity. Mie et al. (2019) reported the conjugation of the aptamer S-MUC-1 (able to bind MUC1 protein) on paclitaxelloaded protein nanoparticles. Incubation of aptamer-modified and bare NPs with MCF-7 cells (that overexpress MUC-1 protein) showed higher uptake levels of aptamer-functionalized NPs when compared to the bare NPs. Further examples of aptamers as ligand for active uptake are reported by Gui et al. (2019) and Yang et al. (2019b). Yang et al. (2019b) modified the surface of mesoporous silica nanoparticles (MSNs) with Sgc8 aptamer able to bind protein tyrosine kinase-7 (PTK-7) on human acute $\mathrm{T}$ lymphocyte leukemia cells. Sgc8-MSNs NPs were also loaded with DOX, in order to enhance drug uptake in leukemia cells. The results obtained with two different cell lines, CCRF-CEM with high expression of PTK-7 and Ramos cells with no expression of PTK-7, showed a high uptake level of Sgc8-MSNs in CCRFCEM cells compared to Ramos cells. Furthermore, no differences in NPs uptake either cell lines was observed using bare MSNs. Gui et al. (2019) used an aptamer designed to bind CD133 receptor on osteosarcoma cells in order to enhance the uptake of lipid NPs loaded with all-trans retinoic acid (ATRA). Results showed high internalization of aptamer-modified NPs in CD133 positive cells compared to the negative ones, confirming the CD133 mediated targeting.

Exploitation of simple molecules to enhance active uptake also includes the use of carbohydrates (Figure 3F). Among these, one of the most studied is hyaluronic acid (HA). This molecule enhances the NPs uptake through its interaction with CD44 protein. Li et al. (2020) recently demonstrated that HA can be easily used to biofunctionalized carbon dots loaded with doxorubicin to enhance drug uptake in CD44 overexpressing cells (4T1). Results obtained by competitive assay performed with free HA showed that the HA-modified NPs were internalized through the binding of HA-modified NPs with the CD44 receptor. Furthermore, in vivo experiments showed that the enhanced accumulation into tumor tissue was confirmed. The use of carbohydrates was also explored for targeted gene-delivery in macrophages by Chen et al. (2020). PLGA-PEG NPs decorated with various carbohydrates (mannose, galactose and dextran) and loaded with eGFP (enhanced Green Fluorescent Protein) mRNA and GFP (Green Fluorescent Protein) plasmid DNA (used as reporters) was developed. The results showed that carbohydrates on the NPs surface, especially mannose and dextran, improved 
the active uptake of carbohydrate-modified-NPs in the Raw 264.7 murine macrophage cell line, that express specific receptors for mannose and dextran.

In addition to the molecules already mentioned, there are other small molecules useful to perform NPs active uptake (Figure 3G). Khan et al. (2020) used folate (FA) to functionalize chitosan-lipid hybrid NPs in order to increase uptake through the interaction of FA with folate receptor (FR), highly expressed on cancer cells. Results showed higher uptake of FA-conjugated $\mathrm{NPs}$ in an ovarian cancer cell line (SK-OV-3) when compared to bare NPs. Similar results were obtained with the 3D spheroid cell model, with a 2.4-fold higher uptake of FA conjugated NPs compared to uptake by the control group. Other simple molecules used to perform NPs active uptake are anisamide (AA) and phenylboronic acid (PBA) able to bind sigma receptors and sialic acid (SA), respectively. These molecules were successfully investigated by Qian X. et al. (2019) and Ramzy et al. (2020). Ramzy et al., functionalized the surface polymeric NPs loaded with thymoquinone (TQ) by using AA, in order to enhance uptake and drug accumulation in colon cancer cells. Researchers used three colon cancer cell lines, HT-29 (overexpressing sigma receptor), HCT-116, and Caco-2, to evaluate the toxicity of AATQ-NPs. Results showed higher toxicity of AA-TQ-NPs in HT-29 cells, compared to the other two cell lines. Furthermore, bare TQ-NPs showed lower toxicity in HT-29 cells compared to AAfunctionalized NPs. These results are due to the active uptake of AA-modified NPs after interaction with the sigma receptor. The use of PBA was described by Qian et al. with soy protein-based NPs. The high affinity of PBA for SA, which is overexpressed in tumor cells, was exploited to enhance the uptake of PBA-modified NPs in cell lines with different SA expression. The results showed a high uptake level of PBA-NPs in HepG2 cells (SA positive) when compared to SH-SY5Y cells (SA negative).

\section{DISCUSSION}

In the last years, the development of nanoparticles functionalization strategies is considerably grown, due to potential applications of NPs in nanomedicine. Surface modification is evolved from the use of simple molecules (PEG), to the aim to decrease toxicity, clearance and immune response, to more specific and complex ligands, in order to increase specificity and efficacy. The evolution of the NPs surface bioconjugation went hand in hand with the identification of specific cellular targets. The possibility to tune the NPs physicochemical properties in combination with the knowledge of cancer biology makes possible the use of these nano-platforms in biomedical applications, both for therapy and diagnostic, providing a great contribution to the advance of nanomedicine.

Uptake and biocompatibility are two of the most important features of a usable nanoplatform for medical applications, and overcoming issues related to these two aspects is the first goal in the development of NPs. For this reason, the study of toxicity and cellular uptake is the first step during the biological assessment of NPs.

The NPs surface modification is a powerful instrument to enhance uptake and biocompatibility, as confirmed by the vast amount of scientific papers focused on this topic. These studies demonstrate that the conjugation of molecules on the NPs surface can effectively enhance biocompatibility both in vivo and in vitro, due to the modification of surface charge and to the inactivation of reactive chemical groups that can affect cellular membrane stability. Moreover, the addition of specific molecules can also enhance NPs passive and active uptake, reducing systemic toxicity in vivo and allowing high precision therapy and/or diagnosis. The binding of molecules on the NP surface can be obtained by covalent and non-covalent approaches. The former is widely used to bind proteins, antibodies, aptamers and peptides exploited to enhance uptake and to perform active targeting, while non-covalent interactions are generally used for loading of drugs and for all molecules that must be released in the cells.

The protocols for the conjugation of molecules on NPs surface depend on the nanomaterial used and on the available functional groups, for this reason the use of linker molecules or the modification of NPs and/or ligands in order to obtain a stable conjugation could be necessary. Furthermore, some molecules used to functionalize NPs have high molecular weight due to the overall size of the proteins and the use of a spacer (e.g., $\mathrm{PEG}_{(\mathrm{n})}$ ) could be necessary to stave off the ligand from NP surface. The use of spacers also has an effect on conjugation density. In fact, in order to bind a sufficient amount of molecules to the NPs it is necessary to reduce steric hindrance. As reported in numerous studies, the conjugation density is a very important parameter that can affect the behavior of NPs. Moreover, it is important to note that the conjugation of some molecules, usually used to enhance uptake, can also increase the NPs biocompatibility.

Due to the high variability of nanomaterials and ligands to modify the NPs surface, it is not possible to follow specific guidelines to functionalize NPs. It is necessary take in account that: (I) the addition of big size molecules could change the size of the NPs, thus influencing uptake; (II) some molecules used for active targeting could change their $3 \mathrm{D}$ structure during the functionalization protocol and to lose the ability to bind target molecules; (III) the conjugation with non-covalent bonds could result in an unstable surface modification due to the influence of environmental conditions like $\mathrm{pH}$ and ionic strength; (IV) the conjugation density and the orientation of ligands on NPs surface is a key parameter to enhance uptake; $(V)$ the reduction of toxicity could be due to a reduction in NPs uptake; and (VI) positively charged NPs are usually better internalized by cells.

In conclusion, through the handling of surface characteristics, the nanoparticles can be transformed in smart platforms, containing therapeutic and imaging agents as well as stealth property, delivering drugs to specific tissues and providing controlled release therapy. This targeted and sustained drug delivery decreases the drug related toxicity and the frequency of treatments. Nanoparticles have proven useful in the treatment of cancer, and many other diseases, also providing advancement in diagnostic and theranostic applications.

\section{AUTHOR CONTRIBUTIONS}

GS and AL designed the review. All authors wrote, read and approved the manuscript. 


\section{REFERENCES}

Abánades Lázaro, I., Haddad, S., Sacca, S., Orellana-Tavra, C., Fairen-Jimenez, D., and Forgan, R. S. (2017). Selective surface PEGylation of UiO-66 nanoparticles for enhanced stability, cell uptake, and $\mathrm{pH}$-responsive drug delivery. Chem 2, 561-578. doi: 10.1016/j.chempr.2017.02.005

Abdollah, M. R. A., Carter, T. J., Jones, C., Kalber, T. L., Rajkumar, V., Tolner, B., et al. (2018). Fucoidan prolongs the circulation time of dextran-coated iron oxide nanoparticles. ACS Nano. 12, 1156-1169. doi: 10.1021/acsnano.7b06734

Adeyemi, J. A., Machado, A. R. T., Ogunjimi, A. T., Alberici, L. C., Antunes, L. M. G., and Barbosa, F. (2020). Cytotoxicity, mutagenicity, oxidative stress and mitochondrial impairment in human hepatoma (HepG2) cells exposed to copper oxide, copper-iron oxide and carbon nanoparticles. Ecotoxicol. Environ. Saf. 189:109982. doi: 10.1016/j.ecoenv.2019.109982

Ahamed, M., Akhtar, M. J., Khan, M. A. M., Alrokayan, S. A., and Alhadlaq, H. A. (2019). Oxidative stress mediated cytotoxicity and apoptosis response of bismuth oxide (Bi2O3) nanoparticles in human breast cancer (MCF-7) cells. Chemosphere 216, 823-831. doi: 10.1016/j.chemosphere.2018.10.214

Ahmad, N., Sharma, A. K., Sharma, S., Khan, I., Sharma, D. K., Shamsi, A., et al. (2019). Biosynthesized composites of Au-Ag nanoparticles using Trapa peel extract induced ROS-mediated p53 independent apoptosis in cancer cells. Drug Chem. Toxicol. 42, 43-53. doi: 10.1080/01480545.2018.1463241

Ahmad, S., Bhattacharya, D., Kar, S., Ranganathan, A., Van Kaer, L., and Das, G. (2019). Curcumin nanoparticles enhance mycobacterium bovis BCG vaccine efficacy by modulating host immune responses. Infect. Immun. 87, e291-e219. doi: 10.1128/IAI.00291-19

Almutary, A., and Sanderson, B. J. S. (2016). The MTT and crystal violet assays: potential confounders in nanoparticle toxicity testing. Int. J. Toxicol. 35, 454462. doi: 10.1177/1091581816648906

Al-Qubaisi, M. S., Rasedee, A., Flaifel, M. H., Ahmad, S. H., Hussein-Al-Ali, S., Hussein, M. Z., et al. (2013a). Induction of apoptosis in cancer cells by $\mathrm{NiZn}$ ferrite nanoparticles through mitochondrial cytochrome $\mathrm{C}$ release. Int. J. Nanomed. 8, 4115-4130. doi: 10.2147/IJN.S50061

Al-Qubaisi, M. S., Rasedee, A., Flaifel, M. H., Ahmad, S. H. J., Hussein-Al-Ali, S., Hussein, M. Z., et al. (2013b). Cytotoxicity of nickel zinc ferrite nanoparticles on cancer cells of epithelial origin. Int. J. Nanomed. 8, 2497-2508. doi: 10.2147/ IJN.S42367

Al-Shakarchi, W., Alsuraifi, A., Abed, M., Abdullah, M., Richardson, A., Curtis, A., et al. (2018). Combined effect of anticancer agents and cytochrome C decorated hybrid nanoparticles for liver cancer therapy. Pharmaceutics 10:48. doi: 10.3390/pharmaceutics10020048

Amin, F. U., Shah, S. A., Badshah, H., Khan, M., and Kim, M. O. (2017). Anthocyanins encapsulated by PLGA@PEG nanoparticles potentially improved its free radical scavenging capabilities via p38/JNK pathway against A $\beta 1$-42induced oxidative stress. J. Nanobiotechnol. 15:6. doi: 10.1186/s12951-0160227-4

Aranda, A., Sequedo, L., Tolosa, L., Quintas, G., Burello, E., Castell, J. V., et al. (2013). Dichloro-dihydro-fluorescein diacetate (DCFH-DA) assay: a quantitative method for oxidative stress assessment of nanoparticle-treated cells. Toxicol. Vitr. 27, 954-963. doi: 10.1016/j.tiv.2013.01.016

Arya, A., Gangwar, A., Singh, S. K., Roy, M., Das, M., Sethy, N. K., et al. (2016). Cerium oxide nanoparticles promote neurogenesis and abrogate hypoxiainduced memory impairment through AMPK-PKC-CBP signaling cascade. Int. J. Nanomed. 11, 1159-1173. doi: 10.2147/IJN.S102096

Asai, T., Tsuzuku, T., Takahashi, S., Okamoto, A., Dewa, T., Nango, M., et al. (2014). Cell-penetrating peptide-conjugated lipid nanoparticles for siRNA delivery. Biochem. Biophys. Res. Commun. 444, 599-604. doi: 10.1016/j.bbrc.2014.01.107

AshaRani, P. V., Sethu, S., Lim, H. K., Balaji, G., Valiyaveettil, S., and Hande, M. P. (2012). Differential regulation of intracellular factors mediating cell cycle, DNA repair and inflammation following exposure to silver nanoparticles in human cells. Genome Integr. 3:2. doi: 10.1186/2041-9414-3-2

Avagliano, A., Ruocco, M. R., Nasso, R., Aliotta, F., Sanità, G., Iaccarino, A., et al. (2019). Development of a stromal microenvironment experimental model containing proto-myofibroblast like cells and analysis of its crosstalk with melanoma cells: a new tool to potentiate and stabilize tumor suppressor phenotype of dermal myofibroblasts. Cells 8:1435. doi: 10.3390/cells8111435

Baharara, J., Ramezani, T., Divsalar, A., Mousavi, M., and Seyedarabi, A. (2016). Induction of apoptosis by green synthesized gold nanoparticles through activation of caspase-3 and 9 in human cervical cancer cells. Avicenna J. Med. Biotechnol. 8, 75-83.

Balas, M., Ciobanu, C. S., Burtea, C., Stan, M. S., Bezirtzoglou, E., Predoi, D., et al. (2017). Synthesis, characterization, and toxicity evaluation of dextran-coated iron oxide nanoparticles. Metals 7:63. doi: 10.3390/met7020063

Bancos, S., Tsai, D.-H., Hackley, V., Weaver, J. L., and Tyner, K. M. (2012). Evaluation of viability and proliferation profiles on macrophages treated with silica nanoparticles in vitro via plate-based, flow cytometry, and coulter counter assays. ISRN Nanotechnol. 2012, 1-11. doi: 10.5402/2012/454072

Banerjee, P. P., Bandyopadhyay, A., Harsha, S. N., Policegoudra, R. S., Bhattacharya, S., Karak, N., et al. (2017). Mentha arvensis (Linn.)-mediated green silver nanoparticles trigger caspase 9-dependent cell death in MCF7 and MDA-MB-231 cells. Breast Cancer Targets Ther. 9, 265-278. doi: 10.2147/ BCTT.S130952

Banihashem, S., Nezhati, M. N., and Panahia, H. A. (2020). Synthesis of chitosangrafted-poly(N-vinylcaprolactam) coated on the thiolated gold nanoparticles surface for controlled release of cisplatin. Carbohydr. Polym. 227:115333. doi: 10.1016/j.carbpol.2019.115333

Bannunah, A. M., Vllasaliu, D., Lord, J., and Stolnik, S. (2014). Mechanisms of nanoparticle internalization and transport across an intestinal epithelial cell model: effect of size and surface charge. Mol. Pharm. 11, 4363-4373. doi: 10. $1021 / \mathrm{mp} 500439 \mathrm{c}$

Barbero, F., Russo, L., Vitali, M., Piella, J., Salvo, I., Borrajo, M. L., et al. (2017). Formation of the protein corona: the interface between nanoparticles and the immune system. Semin. Immunol. 34, 52-60. doi: 10.1016/j.smim.2017.10.001

Barot, T., Rawtani, D., and Kulkarni, P. (2020). Physicochemical and biological assessment of silver nanoparticles immobilized Halloysite nanotubes-based resin composite for dental applications. Heliyon 6:e03601. doi: 10.1016/j. heliyon.2020.e03601

Bejjani, R. A., Benezra, D., Cohen, H., Rieger, J., Andrieu, C., Jeanny, J., et al. (2005). Nanoparticles for gene delivery to retinal pigment epithelial cells. Mol. Vis. 11, 124-132.

Bertrand, N., Wu, J., Xu, X., Kamaly, N., and Farokhzad, O. C. (2014). Cancer nanotechnology: the impact of passive and active targeting in the era of modern cancer biology. Adv. Drug Deliv. Rev. 66, 2-25. doi: 10.1016/j.addr.2013.11.009

Blanco, J., Tomás-Hernández, S., García, T., Mulero, M., Gómez, M., Domingo, J. L., et al. (2018). Oral exposure to silver nanoparticles increases oxidative stress markers in the liver of male rats and deregulates the insulin signalling pathway and p53 and cleaved caspase 3 protein expression. Food Chem. Toxicol. 115, 398-404. doi: 10.1016/j.fct.2018.03.039

Boraschi, D., Italiani, P., Palomba, R., Decuzzi, P., Duschl, A., Fadeel, B., et al. (2017). Nanoparticles and innate immunity: new perspectives on host defence. Semin. Immunol. 34, 33-51. doi: 10.1016/j.smim.2017.08.013

Borkowska, M., Siek, M., Kolygina, D. V., Sobolev, Y. I., Lach, S., Kumar, S., et al. (2020). Targeted crystallization of mixed-charge nanoparticles in lysosomes induces selective death of cancer cells. Nat. Nanotechnol. 15, 331-341. doi: 10.1038/s41565-020-0643-3

Borowik, A., Butowska, K., Konkel, K., Banasiuk, R., Derewonko, N., Wyrzykowski, D., et al. (2019). The impact of surface functionalization on the biophysical properties of silver nanoparticles. Nanomaterials 9:973. doi: 10.3390/ nano9070973

Boyoglu, C., He, Q., Willing, G., Boyoglu-Barnum, S., Dennis, V. A., Pillai, S., et al. (2013). Microscopic studies of various sizes of gold nanoparticles and their cellular localizations. ISRN Nanotechnol. 2013, 1-13. doi: 10.1155/2013/123838

Breus, V. V., Heyes, C. D., Tron, K., and Nienhaus, G. U. (2009). Zwitterionic biocompatible quantum dots for wide $\mathrm{pH}$ stability and weak nonspecific binding to cells. ACS Nano. 3, 2573-2580. doi: 10.1021/nn900 $600 \mathrm{w}$

Brzóska, K., Gradzka, I., and Kruszewski, M. (2019). Silver, gold, and iron oxide nanoparticles alter miRNA expression but do not affect DNA methylation in HepG2 cells. Materials 12;1038. doi: 10.3390/ma12071038

Cao, Z., Peng, F., Hu, Z., Chu, B., Zhong, Y., Su, Y., et al. (2017). In vitro cellular behaviors and toxicity assays of small-sized fluorescent silicon nanoparticles. Nanoscale 9, 7602-7611. doi: 10.1039/c7nr00530j

Cappellano, G., Comi, C., Chiocchetti, A., and Dianzani, U. (2019). Exploiting PLGA-based biocompatible nanoparticles for next-generation tolerogenic vaccines against autoimmune disease. Int. J. Mol. Sci. 20:204. doi: 10.3390/ijms20010204 
Chairuangkitti, P., Lawanprasert, S., Roytrakul, S., Aueviriyavit, S., Phummiratch, D., Kulthong, K., et al. (2013). Silver nanoparticles induce toxicity in A549 cells via ROS-dependent and ROS-independent pathways. Toxicol. In Vitro 27, 330-338. doi: 10.1016/j.tiv.2012.08.021

Chaves, N. L., Estrela-Lopis, I., Böttner, J., Lopes, C., Guido, B. C., De Sousa, A. R., et al. (2017). Exploring cellular uptake of iron oxide nanoparticles associated with rhodium citrate in breast cancer cells. Int. J. Nanomed. 12, 5511-5523. doi: $10.2147 /$ IJN.S141582

Chen, C., Bu, W., Ding, H., Li, Q., Wang, D., Bi, H., et al. (2017). Cytotoxic effect of zinc oxide nanoparticles on murine photoreceptor cells via potassium channel block and $\mathrm{Na}+/ \mathrm{K}+-$ ATPase inhibition. Cell Prolif. 50:e12339. doi: 10.1111/cpr. 12339

Chen, S., Florinas, S., Teitgen, A., Xu, Z. Q., Gao, C., Wu, H., et al. (2017). Controlled Fab installation onto polymeric micelle nanoparticles for tuned bioactivity. Sci. Technol. Adv. Mater. 18, 666-680. doi: 10.1080/14686996.2017. 1370361

Chen, H., and He, S. (2015). PLA-PEG coated multifunctional imaging probe for targeted drug delivery. Mol. Pharm. 12, 1885-1892. doi: 10.1021/mp500512z

Chen, J., Zhang, Y., Zhang, M., Yao, B., Li, Y., Huang, L., et al. (2016). Waterenhanced oxidation of graphite to graphene oxide with controlled species of oxygenated groups. Chem. Sci. 7, 1874-1881. doi: 10.1039/c5sc03828f

Chen, M., He, X., Wang, K., He, D., Yang, X., and Shi, H. (2014). Inorganic fluorescent nanoprobes for cellular and subcellular imaging. TrAC Trends Anal. Chem. 58, 120-129. doi: 10.1016/j.trac.2014.03.003

Chen, M., Yu, X., Huo, Q., Yuan, Q., Li, X., Xu, C., et al. (2019). Biomedical potentialities of silver nanoparticles for clinical multiple drug-resistant Acinetobacter baumannii. J. Nanomater. 2019:7. doi: 10.1155/2019/3754018

Chen, Y., Chen, C., Zhang, X., He, C., Zhao, P., Li, M., et al. (2019). Platinum complexes of curcumin delivered by dual-responsive polymeric nanoparticles improve chemotherapeutic efficacy based on the enhanced anti-metastasis activity and reduce side effects. Acta Pharm. Sin. B. 10, 1106-1121. doi: 10.1016/ j.apsb.2019.10.011

Chen, Q., Gao, M., Li, Z., Xiao, Y., Bai, X., Boakye-Yiadom, K. O., et al. (2020). Biodegradable nanoparticles decorated with different carbohydrates for efficient macrophage-targeted gene therapy. J. Control. Release 323, 179-190. doi: 10. 1016/j.jconrel.2020.03.044

Cheng, Y., Meyers, J. D., Broome, A. M., Kenney, M. E., Basilion, J. P., and Burda, C. (2011). Deep penetration of a PDT drug into tumors by noncovalent druggold nanoparticle conjugates. J. Am. Chem. Soc. 133, 2583-2591. doi: 10.1021/ ja108846h

Chihara, D., Fanale, M. A., Miranda, R. N., Noorani, M., Westin, J. R., Nastoupil, L. J., et al. (2017). The survival outcome of patients with relapsed/refractory peripheral T-cell lymphoma-not otherwise specified and angioimmunoblastic T-cell lymphoma. Br. J. Haematol. 176, 750-758. doi: 10.1111/bjh.14477

Cohen, D. (2017). Cancer drugs: high price, uncertain value. BMJ 359, j4543. doi: 10.1136/bmj.j4543

Corrado, G., Salutari, V., Palluzzi, E., Distefano, M. G., Scambia, G., and Ferrandina, G. (2017). Optimizing treatment in recurrent epithelial ovarian cancer. Expert Rev. Anticancer Ther. 17, 1147-1158. doi: 10.1080/14737140. 2017.1398088

Costanzo, M., Vurro, F., Cisterna, B., Boschi, F., Marengo, A., Montanari, E., et al. (2019). Uptake and intracellular fate of biocompatible nanocarriers in cycling and noncycling cells. Nanomedicine 14, 301-316. doi: 10.2217/nnm-201 8-0148

Cruje, C., and Chithrani, D. B. (2014). Polyethylene glycol density and length affects nanoparticle uptake by cancer cells. J. Nanomed. Res. 1:00006. doi: 10 . 15406/jnmr.2014.01.00006

Cu, Y., and Saltzman, W. M. (2009). Controlled surface modification with poly(ethylene)glycol enhances diffusion of PLGA nanoparticles in human cervical Mucus. Mol. Pharm. 6, 173-181. doi: 10.1021/mp8001254

Da Veiga Moreira, J., Hamraz, M., Abolhassani, M., Bigan, E., Pérès, S., Paulevé, L., et al. (2016). The redox status of cancer cells supports mechanisms behind the Warburg effect. Metabolites 6:33. doi: 10.3390/metabo6040033

de Oliveira, G. M. T., de Oliveira, E. M. N., Pereira, T. C. B., Papaléo, R. M., and Bogo, M. R. (2017). Implications of exposure to dextrancoated and uncoated iron oxide nanoparticles to developmental toxicity in zebrafish. J. Nanoparticle Res. 19:389. doi: 10.1007/s11051-0174074-5
Deirram, N., Zhang, C., Kermaniyan, S. S., Johnston, A. P. R., and Such, G. K. (2019). pH-Responsive polymer nanoparticles for drug delivery. Macromol. Rapid Commun. 40, 1-23. doi: 10.1002/marc.201800917

Desai, D., Prabhakar, N., Mamaeva, V., Karaman, D. Ş, Lähdeniemi, I. A. K., Sahlgren, C., et al. (2016). Targeted modulation of cell differentiation in distinct regions of the gastrointestinal tract via oral administration of differently PEG-PEI functionalized mesoporous silica nanoparticles. Int. J. Nanomed. 11, 299-313. doi: 10.2147/IJN.S94013

Ding, X., Yin, C., Zhang, W., Sun, Y., Zhang, Z., Yang, E., et al. (2020). Designing aptamer-gold nanoparticle-loaded $\mathrm{pH}$-sensitive liposomes encapsulate morin for treating cancer. Nanoscale Res. Lett. 15:68. doi: 10.1186/s11671-02003297-x

Drasler, B., Vanhecke, D., Rodriguez-Lorenzo, L., Petri-Fink, A., and RothenRutishauser, B. (2017). Quantifying nanoparticle cellular uptake: which method is best? Nanomedicine 12, 1095-1099. doi: 10.2217/nnm-2017-1

Drijvers, E., Liu, J., Harizaj, A., Wiesner, U., Braeckmans, K., Hens, Z., et al. (2019). Efficient endocytosis of inorganic nanoparticles with zwitterionic surface functionalization. ACS Appl. Mater. Interfaces 11, 38475-38482. doi: 10.1021/ acsami.9b12398

Duong Le, T. T., Ha, P. T., Tran, T. H. Y., Nguyen, D. T., Nguyen, H. N., Bui, V. K., et al. (2016). In vitro evaluation of Aurora kinase inhibitor -VX680-in formulation of PLA-TPGS nanoparticles. Adv. Nat. Sci. Nanosci. Nanotechnol. 7:025010. doi: 10.1088/2043-6262/7/2/025010

Elkeiy, M. M., Khamis, A. A., El-Gamal, M. M., Abo Gazia, M. M., Zalat, Z. A., and El-Magd, M. A. (2020). Chitosan nanoparticles from Artemia salina inhibit progression of hepatocellular carcinoma in vitro and in vivo. Environ. Sci. Pollut. Res. 27, 19016-19028. doi: 10.1007/s11356-018-3339-6

Elmowafy, E. M., Tiboni, M., and Soliman, M. E. (2019). Biocompatibility, biodegradation and biomedical applications of poly(lactic acid)/poly(lactic-coglycolic acid) micro and nanoparticles. J. Pharm. Investig. 49, 347-380. doi: 10.1007/s40005-019-00439-x

Emami, F., Banstola, A., Vatanara, A., Lee, S., Kim, J. O., Jeong, J. H., et al. (2019). Doxorubicin and anti-PD-L1 antibody conjugated gold nanoparticles for colorectal cancer photochemotherapy. Mol. Pharm. 16, 1184-1199. doi: 10.1021/acs.molpharmaceut.8b01157

Fakhimikabir, H., Tavakoli, M. B., Zarrabi, A., Amouheidari, A., and Rahgozar, S. (2018). The role of folic acid-conjugated polyglycerol coated iron oxide nanoparticles on radiosensitivity with clinical electron beam $(6 \mathrm{MeV})$ on human cervical carcinoma cell line: in vitro study. J. Photochem. Photobiol. B Biol. 182, 71-76. doi: 10.1016/j.jphotobiol.2018.03.023

Fathian kolahkaj, F., Derakhshandeh, K., Khaleseh, F., Azandaryani, A. H., Mansouri, K., and Khazaei, M. (2019). Active targeting carrier for breast cancer treatment: monoclonal antibody conjugated epirubicin loaded nanoparticle. J. Drug Deliv. Sci. Technol. 53:101136. doi: 10.1016/j.jddst.2019.101136

Fehaid, A., and Taniguchi, A. (2019). Size-dependent effect of silver nanoparticles on the tumor necrosis factor $\alpha$-induced dna damage response. Int. J. Mol. Sci. 20:1038. doi: 10.3390/ijms20051038

Feiner-Gracia, N., Dols-Perez, A., Royo, M., Solans, C., Garcia-Celma, M. J., and Fornaguera, C. (2018). Cell penetrating peptide grafting of PLGA nanoparticles to enhance cell uptake. Eur. Polym. J. 108, 429-438. doi: 10.1016/j.eurpolymj. 2018.09.026

Forest, V., Leclerc, L., Hochepied, J. F., Trouvé, A., Sarry, G., and Pourchez, J. (2016). Impact of cerium oxide nanoparticles shape on their in vitro cellular toxicity. Toxicol. Vitr. 38, 136-141. doi: 10.1016/j.tiv.2016.09.022

Forte, E., Fiorenza, D., Torino, E., Costagliola di Polidoro, A., Cavaliere, C., Netti, P. A., et al. (2019). Radiolabeled PET/MRI nanoparticles for tumor imaging. J. Clin. Med. 9:89. doi: 10.3390/jcm9010089

Gaharwar, U. S., Meena, R., and Rajamani, P. (2017). Iron oxide nanoparticles induced cytotoxicity, oxidative stress and DNA damage in lymphocytes. J. Appl. Toxicol. 37, 1232-1244. doi: 10.1002/jat.3485

Gao, H., Yang, Z., Zhang, S., Cao, S., Shen, S., Pang, Z., et al. (2013). Ligand modified nanoparticles increases cell uptake, alters endocytosis and elevates glioma distribution and internalization. Sci. Rep. 3:2534. doi: 10.1038/ srep02534

Ge, X., Fu, Q., Su, L., Li, Z., Zhang, W., Chen, T., et al. (2020). Light-activated gold nanorod vesicles with NIR-II fluorescence and photoacoustic imaging performances for cancer theranostics. Theranostics 10, 4809-4821. doi: 10.7150/ thno. 44376 
Gea, M., Bonetta, S., Iannarelli, L., Giovannozzi, A. M., Maurino, V., Bonetta, S., et al. (2019). Shape-engineered titanium dioxide nanoparticles (TiO 2 -NPs): cytotoxicity and genotoxicity in bronchial epithelial cells. Food Chem. Toxicol. 127, 89-100. doi: 10.1016/j.fct.2019.02.043

Ghosh, M., Sinha, S., Jothiramajayam, M., Jana, A., Nag, A., and Mukherjee, A. (2016). Cyto-genotoxicity and oxidative stress induced by zinc oxide nanoparticle in human lymphocyte cells in vitro and Swiss albino male mice in vivo. Food Chem. Toxicol. 97, 286-296. doi: 10.1016/j.fct.2016.09.025

Gong, H., Xie, Z., Liu, M., Zhu, H., and Sun, H. (2015). Redox-sensitive mesoporous silica nanoparticles functionalized with PEG through a disulfide bond linker for potential anticancer drug delivery. RSC Adv. 5, 59576-59582. doi: $10.1039 / \mathrm{c} 5 \mathrm{ra} 09774 \mathrm{f}$

Gonnissen, D., Qu, Y., Langer, K., Öztürk, C., Zhao, Y., Chen, C., et al. (2016). Comparison of cellular effects of starch-coated SPIONs and poly(Lactic-coglycolic acid) matrix nanoparticles on human monocytes. Int. J. Nanomed. 11, 5221-5236. doi: 10.2147/IJN.S106540

Grahovac, J., Srdić-Rajić, T., Santibañez, J. F., Pavlović, M., Čavić, M., and Radulović, S. (2019). Telmisartan induces melanoma cell apoptosis and synergizes with vemurafenib in vitro by altering cell bioenergetics. Cancer Biol. Med. 16, 247-263. doi: 10.20892/j.issn.2095-3941.2018.0375

Grudzinski, I. P., Bystrzejewski, M., Cywinska, M. A., Kosmider, A., Poplawska, M., Cieszanowski, A., et al. (2013). Cytotoxicity evaluation of carbon-encapsulated iron nanoparticles in melanoma cells and dermal fibroblasts. J. Nanoparticle Res. 15:1835. doi: 10.1007/s11051-013-1835-7

Gu, P., Wusiman, A., Wang, S., Zhang, Y., Liu, Z., Hu, Y., et al. (2019). Polyethylenimine-coated PLGA nanoparticles-encapsulated Angelica sinensis polysaccharide as an adjuvant to enhance immune responses. Carbohydr. Polym. 223:115128. doi: 10.1016/j.carbpol.2019.115128

Guerrini, L., Alvarez-Puebla, R. A., and Pazos-Perez, N. (2018). Surface modifications of nanoparticles for stability in biological fluids. Materials 11:1154. doi: 10.3390/ma11071154

Gui, K., Zhang, X., Chen, F., Ge, Z., Zhang, S., Qi, X., et al. (2019). Lipid-polymer nanoparticles with CD133 aptamers for targeted delivery of all-trans retinoic acid to osteosarcoma initiating cells. Biomed. Pharmacother. 111, 751-764. doi: 10.1016/j.biopha.2018.11.118

Gurunathan, S., Qasim, M., Park, C., Yoo, H., Kim, J. H., and Hong, K. (2018). Cytotoxic potential and molecular pathway analysis of silver nanoparticles in human colon cancer cells HCT116. Int. J. Mol. Sci. 19:2269. doi: 10.3390/ ijms 19082269

Han, N., Wang, Y., Bai, J., Liu, J., Wang, Y., Gao, Y., et al. (2016). Facile synthesis of the lipid bilayer coated mesoporous silica nanocomposites and their application in drug delivery. Microporous Mesoporous Mater. 219, 209-218. doi: 10.1016/j. micromeso.2015.08.006

Harrison, E., Nicol, J. R., Macias-Montero, M., Burke, G. A., Coulter, J. A., Meenan, B. J., et al. (2016). A comparison of gold nanoparticle surface cofunctionalization approaches using Polyethylene Glycol (PEG) and the effect on stability, non-specific protein adsorption and internalization. Mater. Sci. Eng. C 62, 710-718. doi: 10.1016/j.msec.2016.02.003

Hernandez-Delgadillo, R., García-Cuéllar, C. M., Sánchez-Pérez, Y., PinedaAguilar, N., Martínez-Martínez, M. A., Rangel-Padilla, E. E., et al. (2018). In vitro evaluation of the antitumor effect of bismuth lipophilic nanoparticles (BisBAL NPs) on breast cancer cells. Int. J. Nanomed. 13, 6089-6097. doi: 10.2147/IJN.S179095

Hernández-Ortiz, M., Acosta-Torres, L. S., Hernández-Padrón, G., Mendieta, A. I., Bernal, R., Cruz-Vázquez, C., et al. (2012). Biocompatibility of crystalline opal nanoparticles. Biomed. Eng. Online 11:78. doi: 10.1186/1475-925X-11-78

Houdaihed, L., Evans, J. C., and Allen, C. (2020). Dual-targeted delivery of nanoparticles encapsulating paclitaxel and everolimus: a novel strategy to overcome breast cancer receptor heterogeneity. Pharm. Res. 37:39. doi: 10.1007/ s11095-019-2684-6

Hu, J., Dong, Y., Ding, L., Dong, Y., Wu, Z., Wang, W., et al. (2019). Local delivery of arsenic trioxide nanoparticles for hepatocellular carcinoma treatment. Signal Transduct. Target. Ther. 4:28. doi: 10.1038/s41392-019-0062-9

Huai, Y., Hossen, M. N., Wilhelm, S., Bhattacharya, R., and Mukherjee, P. (2019). Nanoparticle interactions with the tumor microenvironment. Bioconjug. Chem. 30, 2247-2263. doi: 10.1021/acs.bioconjchem.9b00448

Iglesias, T., López de Cerain, A., Irache, J. M., Martín-Arbella, N., Wilcox, M., Pearson, J., et al. (2017). Evaluation of the cytotoxicity, genotoxicity and mucus permeation capacity of several surface modified poly(anhydride) nanoparticles designed for oral drug delivery. Int. J. Pharm. 517, 67-79. doi: 10.1016/j. ijpharm.2016.11.059

Jayaram, D. T., Runa, S., Kemp, M. L., and Payne, C. K. (2017). Nanoparticleinduced oxidation of corona proteins initiates an oxidative stress response in cells. Nanoscale 9, 7595-7601. doi: 10.1039/c6nr09500c

Jeevanandam, J., Barhoum, A., Chan, Y. S., Dufresne, A., and Danquah, M. K. (2018). Review on nanoparticles and nanostructured materials: history, sources, toxicity and regulations. Beilstein J. Nanotechnol. 9, 1050-1074. doi: 10.3762/ bjnano.9.98

Jeon, S., Clavadetscher, J., Lee, D. K., Chankeshwara, S. V., Bradley, M., and Cho, W. S. (2018). Surface charge-dependent cellular uptake of polystyrene nanoparticles. Nanomaterials 8:1028. doi: 10.3390/NANO8121028

Jiang, Y., Li, Y., Richard, C., Scherman, D., and Liu, Y. (2019). Hemocompatibility investigation and improvement of near-infrared persistent luminescent nanoparticle $\mathrm{ZnGa2O}$ :Cr3+ by surface PEGylation. J. Mater. Chem. B 7, 3796-3803. doi: 10.1039/c9tb00378a

Jochums, A., Friehs, E., Sambale, F., Lavrentieva, A., Bahnemann, D., and Scheper, T. (2017). Revelation of different nanoparticle-uptake behavior in two standard cell lines NIH/3T3 and A549 by flow cytometry and time-lapse imaging. Toxics 5:15. doi: 10.3390/toxics5030015

Jung, E., Kang, C., Lee, J., Yoo, D., Hwang, D. W., Kim, D., et al. (2018). Molecularly engineered theranostic nanoparticles for thrombosed vessels: $\mathrm{H} 2 \mathrm{O} 2$-activatable contrast-enhanced photoacoustic imaging and antithrombotic therapy. ACS Nano 12, 392-401. doi: 10.1021/acsnano.7b06560

Jung, H. S., Moon, D. S., and Lee, J. K. (2012). Quantitative analysis and efficient surface modification of silica nanoparticles. J. Nanomater. 2012:593471. doi: $10.1155 / 2012 / 593471$

Kalaiarasi, A., Sankar, R., Anusha, C., Saravanan, K., Aarthy, K., Karthic, S., et al. (2018). Copper oxide nanoparticles induce anticancer activity in A549 lung cancer cells by inhibition of histone deacetylase. Biotechnol. Lett. 40, 249-256. doi: 10.1007/s10529-017-2463-6

Kang, S. J., Kim, B. M., Lee, Y. J., Hong, S. H., and Chung, H. W. (2009). Titanium dioxide nanoparticles induce apoptosis through the JNK/p38-caspase-8-Bid pathway in phytohemagglutinin-stimulated human lymphocytes. Biochem. Biophys. Res. Commun. 386, 682-687. doi: 10.1016/j.bbrc.2009.06.097

Karlsson, H. L., Cronholm, P., Gustafsson, J., and Mo, L. (2008). Copper oxide nanoparticles are highly toxic a comparison between metal oxide nanoparticles and carbon nanotubes - chemical research in toxicology (ACS Publications). Chem. Res. Toxicol. 21, 1726-1732.

Karlsson, H. L., Cronholm, P., Hedberg, Y., Tornberg, M., De Battice, L., Svedhem, S., et al. (2013). Cell membrane damage and protein interaction induced by copper containing nanoparticles-Importance of the metal release process. Toxicology 313, 59-69. doi: 10.1016/j.tox.2013.07.012

Khan, F. A., Akhtar, S., Almohazey, D., Alomari, M., Almofty, S. A., Badr, I., et al. (2019). Targeted delivery of poly (methyl methacrylate) particles in colon cancer cells selectively attenuates cancer cell proliferation. Artif. Cells, Nanomedicine Biotechnol. 47, 1533-1542. doi: 10.1080/21691401.2019.1577886

Khan, M. M., Madni, A., Filipczak, N., Pan, J., Rehman, M., Rai, N., et al. (2020). Folate targeted lipid chitosan hybrid nanoparticles for enhanced anti-tumor efficacy. Nanomed. Nanotechnol. Biol. Med. 28:102228. doi: 10.1016/j.nano. 2020.102228

Khanna, V., Kalscheuer, S., Kirtane, A., Zhang, W., and Panyam, J. (2019). Perlecan-targeted nanoparticles for drug delivery to triple-negative breast cancer. Futur. Drug Discov. 1:FDD8. doi: 10.4155/fdd-2019-2015

Khdair, A., Chen, D. I., Patil, Y., Ma, L., Dou, Q. P., Shekhar, M. P. V., et al. (2010). Nanoparticle-mediated combination chemotherapy and photodynamic therapy overcomes tumor drug resistance. J. Control. Release 141, 137-144. doi: 10.1016/j.jconrel.2009.09.004

Kiang Chua, C., and Pumera, M. (2013). Covalent chemistry on graphene. Chem. Soc. Rev. 42, 3222-3233. doi: 10.1039/c2cs35474h

Kim, D. Y., Kim, J. H., Lee, J. C., Won, M. H., Yang, S. R., Kim, H. C., et al. (2019). Zinc oxide nanoparticles exhibit both cyclooxygenaseand lipoxygenase-mediated apoptosis in human bone marrow-derived mesenchymal stem cells. Toxicol. Res. 35, 83-91. doi: 10.5487/TR.2019.3 5.1 .083

Kim, M. S., Park, B. C., Kim, Y. J., Lee, J. H., Koo, T. M., Ko, M. J., et al. (2020). Design of magnetic-plasmonic nanoparticle assemblies via interface 
engineering of plasmonic shells for targeted cancer cell imaging and separation. Small 16:e2001103. doi: 10.1002/smll.202001103

Kinoda, J., Ishihara, M., Hattori, H., Nakamura, S., Fukuda, K., and Yokoe, H. (2016). Cytotoxicity of silver nanoparticle and chitin-nanofiber sheet composites caused by oxidative stress. Nanomaterials 6:189. doi: 10.3390/ nano6100189

Kiplagat, A., Martin, D. R., Onani, M. O., and Meyer, M. (2019). Aptamerconjugated magnetic nanoparticles for the efficient capture of cancer biomarker proteins. J. Magn. Magn. Mater. 497:166063. doi: 10.1016/j.jmmm.2019.166063

Korpany, K. V., Mottillo, C., Bachelder, J., Cross, S. N., Dong, P., Trudel, S., et al. (2016). One-step ligand exchange and switching from hydrophobic to water-stable hydrophilic superparamagnetic iron oxide nanoparticles by mechanochemical milling. Chem. Commun. 52, 3054-3057. doi: 10.1039/ c5cc07107k

Kostiv, U., Patsula, V., Šlouf, M., Pongrac, I. M., Škokić, S., Radmilović, M. D., et al. (2017). Physico-chemical characteristics, biocompatibility, and MRI applicability of novel monodisperse PEG-modified magnetic Fe3O4\&SiO2 core-shell nanoparticles. RSC Adv. 7, 8786-8797. doi: 10.1039/c7ra00224f

Kumar, G., Degheidy, H., Casey, B. J., and Goering, P. L. (2015). Flow cytometry evaluation of in vitro cellular necrosis and apoptosis induced by silver nanoparticles. Food Chem. Toxicol. 85, 45-51. doi: 10.1016/j.fct.2015.06.012

Kumar, P., Van Treuren, T., Ranjan, A. P., Chaudhary, P., and Vishwanatha, J. K. (2019). In vivo imaging and biodistribution of near infrared dye loaded brain-metastatic-breast-cancer-cell-membrane coated polymeric nanoparticles. Nanotechnology 30:265101. doi: 10.1088/1361-6528/ab0f46

Kutwin, M., Sawosz, E., Jaworski, S., Wierzbicki, M., Strojny, B., Grodzik, M., et al. (2019). Nanocomplexes of graphene oxide and platinum nanoparticles against colorectal cancer colo205, HT-29, HTC-116, SW480, liver cancer HepG2, human breast cancer MCF-7, and adenocarcinoma LNCaP and human cervical Hela B cell lines. Materials 12:909. doi: 10.3390/ma12060909

Large, D. E., Soucy, J. R., Hebert, J., and Auguste, D. T. (2019). Advances in receptor-mediated, tumor-targeted drug delivery. Adv. Ther. 2:1800091. doi: 10.1002/adtp.201800091

Li, C., Cai, G., Song, D., Gao, R., Teng, P., Zhou, L. H., et al. (2019a). Development of EGFR-targeted evodiamine nanoparticles for the treatment of colorectal cancer. Biomater. Sci. 7, 3627-3639. doi: 10.1039/c9bm00613c

Li, C., Wang, Y., Zhang, H., Li, M., Zhu, Z., and Xue, Y. (2019b). An investigation on the cytotoxicity and caspase-mediated apoptotic effect of biologically synthesized gold nanoparticles using Cardiospermum halicacabum on AGS gastric carcinoma cells. Int. J. Nanomed. 14, 951-962. doi: 10.2147/IJN.S193064

Li, Y., Zeng, S., and Hao, J. (2019c). Non-Invasive optical guided tumor metastasis/vessel imaging by using lanthanide nanoprobe with enhanced downshifting emission beyond $1500 \mathrm{~nm}$. ACS Nano. 13, 248-259. doi: 10.1021/ acsnano.8b05431

Li, D., Zhang, M., Xu, F., Chen, Y., Chen, B., Chang, Y., et al. (2018). Biomimetic albumin-modified gold nanorods for photothermo-chemotherapy and macrophage polarization modulation. Acta Pharm. Sin. B 8, 74-84. doi: 10.1016/j.apsb.2017.09.005

Li, Q., Huang, C., Liu, L., Hu, R., and Qu, J. (2018). Effect of surface coating of gold nanoparticles on cytotoxicity and cell cycle progression. Nanomaterials 8:1063. doi: 10.3390/NANO8121063

Li, J., Li, M., Tian, L., Qiu, Y., Yu, Q., Wang, X., et al. (2020). Facile strategy by hyaluronic acid functional carbon dot-doxorubicin nanoparticles for CD44 targeted drug delivery and enhanced breast cancer therapy. Int. J. Pharm. 578:119122. doi: 10.1016/j.ijpharm.2020.119122

Liu, T., Bai, R., Zhou, H., Wang, R., Liu, J., Zhao, Y., et al. (2020). The effect of size and surface ligands of iron oxide nanoparticles on blood compatibility. RSC Adv. 10, 7559-7569. doi: 10.1039/c9ra10969b

Liu, Y., Li, W., Lao, F., Liu, Y., Wang, L., Bai, R., et al. (2011). Intracellular dynamics of cationic and anionic polystyrene nanoparticles without direct interaction with mitotic spindle and chromosomes. Biomaterials 32, 8291-8303. doi: 10.1016/j.biomaterials.2011.07.037

Ludwig, R., Teran, F. J., Teichgraeber, U., and Hilger, I. (2017). Nanoparticlebased hyperthermia distinctly impacts production of ROS, expression of Ki-67, TOP2A, and TPX2, and induction of apoptosis in pancreatic cancer. Int. J. Nanomed. 12, 1009-1018. doi: 10.2147/IJN.S108577
Luo, C., Li, Y., Yang, L., Wang, X., Long, J., and Liu, J. (2015). Superparamagnetic iron oxide nanoparticles exacerbate the risks of reactive oxygen speciesmediated external stresses. Arch. Toxicol. 89, 357-369. doi: 10.1007/s00204014-1267-x

Luo, Y., Cai, X., Li, H., Lin, Y., and Du, D. (2016). Hyaluronic acid-modified multifunctional Q-graphene for targeted killing of drug-resistant lung cancer cells. ACS Appl. Mater. Interfaces 8, 4048-4055. doi: 10.1021/acsami.5b11471

Lv, Y., Hao, L., Hu, W., Ran, Y., Bai, Y., and Zhang, L. (2016). Novel multifunctional $\mathrm{pH}$-sensitive nanoparticles loaded into microbubbles as drug delivery vehicles for enhanced tumor targeting. Sci. Rep. 6:29321. doi: 10.1038/srep29321

Maeda, H. (2015). Toward a full understanding of the EPR effect in primary and metastatic tumors as well as issues related to its heterogeneity. Adv. Drug Deliv. Rev. 91, 3-6. doi: 10.1016/j.addr.2015.01.002

Managò, S., Migliaccio, N., Terracciano, M., Napolitano, M., Martucci, N. M., De Stefano, L., et al. (2018). Internalization kinetics and cytoplasmic localization of functionalized diatomite nanoparticles in cancer cells by Raman imaging. J. Biophotonics 11:e201700207. doi: 10.1002/jbio.201700207

Marino, A., Battaglini, M., De Pasquale, D., Degl'Innocenti, A., and Ciofani, G. (2018). Ultrasound-activated piezoelectric nanoparticles inhibit proliferation of breast cancer cells. Sci. Rep. 8:6257. doi: 10.1038/s41598-018-24697-1

Marrugo-Ramírez, J., Mir, M., and Samitier, J. (2018). Blood-based cancer biomarkers in liquid biopsy: a promising non-invasive alternative to tissue biopsy. Int. J. Mol. Sci. 19:2877. doi: 10.3390/ijms19102877

Martucci, N. M., Migliaccio, N., Ruggiero, I., Albano, F., Calì, G., Romano, S., et al. (2016). Nanoparticle-based strategy for personalized B-cell lymphoma therapy. Int. J. Nanomed. 11, 6089-6101. doi: 10.2147/IJN.S118661

McDaid, W. J., Greene, M. K., Johnston, M. C., Pollheimer, E., Smyth, P., McLaughlin, K., et al. (2019). Repurposing of Cetuximab in antibody-directed chemotherapy-loaded nanoparticles in EGFR therapy-resistant pancreatic tumours. Nanoscale 11, 20261-20273. doi: 10.1039/c9nr07257h

Men, W., Zhu, P., Dong, S., Liu, W., Zhou, K., Bai, Y., et al. (2020). Layer-bylayer $\mathrm{pH}$-sensitive nanoparticles for drug delivery and controlled release with improved therapeutic efficacy in vivo. Drug Deliv. 27, 180-190. doi: 10.1080/ 10717544.2019.1709922

Mie, M., Matsumoto, R., Mashimo, Y., Cass, A. E. G., and Kobatake, E. (2019). Development of drug-loaded protein nanoparticles displaying enzymaticallyconjugated DNA aptamers for cancer cell targeting. Mol. Biol. Rep. 46, 261-269. doi: 10.1007/s11033-018-4467-2

Mosquera, J., Henriksen-Lacey, M., García, I., Martínez-Calvo, M., Rodríguez, J., Mascareñas, J. L., et al. (2018). Cellular uptake of gold nanoparticles triggered by host-guest interactions. J. Am. Chem. Soc. 140, 4469-4472. doi: 10.1021/jacs. $7 \mathrm{~b} 12505$

Muro, E., Pons, T., Lequeux, N., Fragola, A., Sanson, N., Lenkei, Z., et al. (2010). Small and stable sulfobetaine zwitterionic quantum dots for functional live-cell imaging. J. Am. Chem. Soc. 132, 4556-4557. doi: 10.1021/ja100 5493

Naves, L. B., Dhand, C., Venugopal, J. R., Rajamani, L., Ramakrishna, S., and Almeida, L. (2017). Nanotechnology for the treatment of melanoma skin cancer. Prog. Biomater. 6, 13-26. doi: 10.1007/s40204-017-0064-z

Nell, K. M., Fontenot, S. A., Carter, T. G., Warner, M. G., Warner, C. L., Addleman, R. S., et al. (2016). Non-covalent functionalization of high-surface area nanomaterials: a new class of sorbent materials. Environ. Sci. Nano. 3, 138-145. doi: 10.1039/c5en00170f

Ng, C. T., Yong, L. Q., Hande, M. P., Ong, C. N., Yu, L. E., Bay, B. H., et al. (2017). Zinc oxide nanoparticles exhibit cytotoxicity and genotoxicity through oxidative stress responses in human lung fibroblasts and Drosophila melanogaster. Int. J. Nanomed. 12, 1621-1637. doi: 10.2147/IJN.S124403

Nobs, L., Buchegger, F., Gurny, R., and Allémann, E. (2004). Current methods for attaching targeting ligands to liposomes and nanoparticles. J. Pharm. Sci. 93, 1980-1992. doi: 10.1002/jps.20098

Oriana, S., Fracassi, A., Archer, C., and Yamakoshi, Y. (2018). Covalent surface modification of lipid nanoparticles by rapid potassium acyltrifluoroborate amide ligation. Langmuir 34, 13244-13251. doi: 10.1021/acs.langmuir.8b01945

Oun, R., Moussa, Y. E., and Wheate, N. J. (2018). The side effects of platinumbased chemotherapy drugs: a review for chemists. Dalt. Trans. 47, 6645-6653. doi: $10.1039 / \mathrm{c} 8 \mathrm{dt} 00838 \mathrm{~h}$ 
Pagels, R. F., Pinkerton, N. M., York, A. W., and Prud'homme, R. K. (2020). Synthesis of heterobifunctional thiol-poly(lactic acid)-b-poly(ethylene glycol)hydroxyl for nanoparticle drug delivery applications. Macromol. Chem. Phys. 221:1900396. doi: 10.1002/macp.201900396

Panebianco, F., Climent, M., Malvindi, M. A., Pompa, P. P., Bonetti, P., and Nicassio, F. (2019). Delivery of biologically active miR-34a in normal and cancer mammary epithelial cells by synthetic nanoparticles. Nanomed. Nanotechnol. Biol. Med. 19, 95-105. doi: 10.1016/j.nano.2019.03.013

Parvanian, S., Mostafavi, S. M., and Aghashiri, M. (2017). Multifunctional nanoparticle developments in cancer diagnosis and treatment. Sens. Bio Sensing Res. 13, 81-87. doi: 10.1016/j.sbsr.2016.08.002

Patgiri, A., Skinner, O. S., Miyazaki, Y., Schleifer, G., Marutani, E., Shah, H., et al. (2020). An engineered enzyme that targets circulating lactate to alleviate intracellular NADH:NAD+ imbalance. Nat. Biotechnol. 38, 309-313. doi: 10. 1038/s41587-019-0377-7

Peng, Y., Song, C., Yang, C., Guo, Q., and Yao, M. (2017). Low molecular weight chitosan-coated silver nanoparticles are effective for the treatment of MRSA-infected wounds. Int. J. Nanomed. 12, 295-304. doi: 10.2147/IJN.S12 2357

Phuong, P. T. T., Lee, S., Lee, C., Seo, B., Park, S., Oh, K. T., et al. (2018). Betacarotene-bound albumin nanoparticles modified with chlorin e6 for breast tumor ablation based on photodynamic therapy. Colloids Surf. B Biointerfaces 171, 123-133. doi: 10.1016/j.colsurfb.2018.07.016

Pinzaru, I., Coricovac, D., Dehelean, C., Moacă, E. A., Mioc, M., Baderca, F., et al. (2018). Stable PEG-coated silver nanoparticles - A comprehensive toxicological profile. Food Chem. Toxicol. 111, 546-556. doi: 10.1016/j.fct.2017.11.051

Plackal Adimuriyil George, B., Kumar, N., Abrahamse, H., and Ray, S. S. (2018). Apoptotic efficacy of multifaceted biosynthesized silver nanoparticles on human adenocarcinoma cells. Sci. Rep. 8:14368. doi: 10.1038/s41598-01832480-5

Poh, H. L., Šimek, P., Sofer, Z., and Pumera, M. (2013). Halogenation of graphene with chlorine, bromine, or iodine by exfoliation in a halogen atmosphere. Chem. A Eur. J. 19, 2655-2662. doi: 10.1002/chem.201202972

Popov, A. L., Han, B., Ermakov, A. M., Savintseva, I. V., Ermakova, O. N., Popova, N. R., et al. (2020). PVP-stabilized tungsten oxide nanoparticles: $\mathrm{pH}$ sensitive anti-cancer platform with high cytotoxicity. Mater. Sci. Eng. C 108:110494. doi: 10.1016/j.msec.2019.110494

Popovtzer, A., Mizrachi, A., Motiei, M., Bragilovski, D., Lubimov, L., Levi, M., et al. (2016). Actively targeted gold nanoparticles as novel radiosensitizer agents: an in vivo head and neck cancer model. Nanoscale 8, 2678-2685. doi: 10.1039/ c5nr07496g

Qian, Q., Niu, S., Williams, G. R., Wu, J., Zhang, X., and Zhu, L. M. (2019). Peptide functionalized dual-responsive chitosan nanoparticles for controlled drug delivery to breast cancer cells. Colloids Surfaces A Physicochem. Eng. Asp. 564, 122-130. doi: 10.1016/j.colsurfa.2018.12.026

Qian, X., Ge, L., Yuan, K., Li, C., Zhen, X., Cai, W., et al. (2019). Targeting and microenvironment-improving of phenylboronic acid-decorated soy protein nanoparticles with different sizes to tumor. Theranostics 9, 7417-7430. doi: 10.7150/thno.33470

Qie, Y., Yuan, H., Von Roemeling, C. A., Chen, Y., Liu, X., Shih, K. D., et al. (2016). Surface modification of nanoparticles enables selective evasion of phagocytic clearance by distinct macrophage phenotypes. Sci. Rep. 6:26269. doi: 10.1038/ srep26269

Ramzy, L., Metwally, A. A., Nasr, M., and Awad, G. A. S. (2020). Novel thymoquinone lipidic core nanocapsules with anisamide-polymethacrylate shell for colon cancer cells overexpressing sigma receptors. Sci. Rep. 10:10987. doi: 10.1038/s41598-020-67748-2

Rancan, F., Gao, Q., Graf, C., Troppens, S., Hadam, S., Hackbarth, S., et al. (2012). Skin penetration and cellular uptake of amorphous silica nanoparticles with variable size, surface functionalization, and colloidal stability. ACS Nano. 6, 6829-6842. doi: 10.1021/nn3 $01622 \mathrm{~h}$

Rea, I., Martucci, N. M., De Stefano, L., Ruggiero, I., Terracciano, M., Dardano, P., et al. (2014). Diatomite biosilica nanocarriers for siRNA transport inside cancer cells. Biochim. Biophys. Acta Gen. Subj. 1840, 3393-3403. doi: 10.1016/j.bbagen. 2014.09.009

Reece-Mills, M., Bath, L. E., Kelnar, C. J., Wallace, H. B., Keys, C., and Carachi, R. (2016). "Long-term effects of childhood cancer therapy on growth and fertility," in The Surgery of Childhood Tumors, eds R. Carachi and J. L. Grosfeld (Berlin: Springer Berlin Heidelberg), 657-670. doi: 10.1007/978-3-662-48590-3_35

Rees, P., Wills, J. W., Brown, M. R., Barnes, C. M., and Summers, H. D. (2019). The origin of heterogeneous nanoparticle uptake by cells. Nat. Commun. 10:2341. doi: 10.1038/s41467-019-10112-4

Rio-Echevarria, I. M., Ponti, J., Bogni, A., Gilliland, D., Altissimo, M., Pascolo, L., et al. (2019). XRF mapping and TEM analysis of coated and uncoated silica nanoparticles in A549 cells and human monocytes. X-Ray Spectrom. 48, 94-101. doi: $10.1002 / x r s .2999$

Rudramurthy, G. R., and Swamy, M. K. (2018). Potential applications of engineered nanoparticles in medicine and biology: an update. J. Biol. Inorg. Chem. 23, 1185-1204. doi: 10.1007/s00775-018-1600-6

Ruizendaal, L., Bhattacharjee, S., Pournazari, K., Rosso-Vasic, M., De Haan, L. H. J., Alink, G. M., et al. (2009). Synthesis and cytotoxicity of silicon nanoparticles with covalently attached organic monolayers. Nanotoxicology 3, 339-347. doi: $10.3109 / 17435390903288896$

Sakaguchi, M., Makino, M., Ohura, T., Yamamoto, K., Enomoto, Y., and Takase, H. (2019). Surface modification of Fe 3 O 4 nanoparticles with dextran via a coupling reaction between naked $\mathrm{Fe} 3 \mathrm{O} 4$ mechano-cation and naked dextran mechano-anion: a new mechanism of covalent bond formation. Adv. Powder Technol. 30, 795-806. doi: 10.1016/j.apt.2019.01.008

Salahpour Anarjan, F. (2019). Active targeting drug delivery nanocarriers: ligands. Nano Struct. Nano Objects 19:100370. doi: 10.1016/j.nanoso.2019.100370

Sanità, G., Armanetti, P., Silvestri, B., Carrese, B., Calì, G., Pota, G., et al. (2020). Albumin-modified melanin-silica hybrid nanoparticles target breast cancer cells via a SPARC-dependent mechanism. Front. Bioeng. Biotechnol. 8:765. doi: 10.3389/FBIOE.2020.00765

Santos-Rasera, J. R., Sant'Anna Neto, A., Rosim Monteiro, R. T., Van Gestel, C. A. M., Pereira, and De Carvalho, H. W. (2019). Toxicity, bioaccumulation and biotransformation of $\mathrm{Cu}$ oxide nanoparticles in: daphnia magna. Environ. Sci. Nano. 6, 2897-2906. doi: 10.1039/c9en00280d

Scheeren, L. E., Nogueira-Librelotto, D. R., Macedo, L. B., de Vargas, J. M., Mitjans, M., Vinardell, M. P., et al. (2020). Transferrin-conjugated doxorubicin-loaded PLGA nanoparticles with $\mathrm{pH}$-responsive behavior: a synergistic approach for cancer therapy. J. Nanoparticle Res. 22:72. doi: 10.1007/s11051-020-04798-7

Schirrmacher, V. (2019). From chemotherapy to biological therapy: a review of novel concepts to reduce the side effects of systemic cancer treatment (Review). Int. J. Oncol. 54, 407-419. doi: 10.3892/ijo.2018.4661

Shen, Z., Chen, T., Ma, X., Ren, W., Zhou, Z., Zhu, G., et al. (2017). Multifunctional theranostic nanoparticles based on exceedingly small magnetic iron oxide nanoparticles for T1-weighted magnetic resonance imaging and chemotherapy. ACS Nano. 11, 10992-11004. doi: 10.1021/acsnano.7b04924

Shukla, S., Jadaun, A., Arora, V., Sinha, R. K., Biyani, N., and Jain, V. K. (2015). In vitro toxicity assessment of chitosan oligosaccharide coated iron oxide nanoparticles. Toxicol. Rep. 2, 27-39. doi: 10.1016/j.toxrep.2014.11.002

Silvestri, B., Armanetti, P., Sanità, G., Vitiello, G., Lamberti, A., Calì, G., et al. (2019). Silver-nanoparticles as plasmon-resonant enhancers for eumelanin's photoacoustic signal in a self-structured hybrid nanoprobe. Mater. Sci. Eng. C 102, 788-797. doi: 10.1016/j.msec.2019.04.066

Singh, M. S., and Lamprecht, A. (2016). P-glycoprotein inhibition of drug resistant cell lines by nanoparticles. Drug Dev. Ind. Pharm. 42, 325-331. doi: 10.3109/ 03639045.2015 .1054396

Song, G., Kenney, M., Chen, Y. S., Zheng, X., Deng, Y., Chen, Z., et al. (2020). Carbon-coated FeCo nanoparticles as sensitive magnetic-particle-imaging tracers with photothermal and magnetothermal properties. Nat. Biomed. Eng. 4, 325-334. doi: 10.1038/s41551-019-0506-0

Suganuma, K., Yamasaki, S., Molefe, N. I., Musinguzi, P. S., Davaasuren, B., Mossaad, E., et al. (2017). The establishment of in vitro culture and drug screening systems for a newly isolated strain of Trypanosoma equiperdum. Int. J. Parasitol. Drugs Drug Resist. 7, 200-205. doi: 10.1016/j.ijpddr.2017.04.002

Surapaneni, S. K., Bashir, S., and Tikoo, K. (2018). Gold nanoparticles-induced cytotoxicity in triple negative breast cancer involves different epigenetic alterations depending upon the surface charge. Sci. Rep. 8:12295. doi: 10.1038/ s41598-018-30541-3

Suzuki, H., Toyooka, T., and Ibuki, Y. (2007). Simple and easy method to evaluate uptake potential of nanoparticles in mammalian cells using a flow cytometric light scatter analysis. Environ. Sci. Technol. 41, 3018-3024. doi: $10.1021 /$ es0625632 
Świetek, M., Lu, Y. C., Konefał, R., Ferreira, L. P., Cruz, M. M., Ma, Y. H., et al. (2019). Scavenging of reactive oxygen species by phenolic compound-modified maghemite nanoparticles. Beilstein J. Nanotechnol. 10, 1073-1088.

Tai, L. A., Tsai, P. J., Wang, Y. C., Wang, Y. J., Lo, L. W., and Yang, C. S. (2009). Thermosensitive liposomes entrapping iron oxide nanoparticles for controllable drug release. Nanotechnology 20:135101.

Taleb, M., Ding, Y., Wang, B., Yang, N., Han, X., Du, C., et al. (2019). Dopamine delivery via $\mathrm{pH}$-sensitive nanoparticles for tumor blood vessel normalization and an improved effect of cancer chemotherapeutic drugs. Adv. Healthc. Mater. 8:e1900283. doi: 10.1002/adhm.201900283

Tammaro, O., Costagliola di Polidoro, A., Romano, E., Netti, P. A., and Torino, E. (2020). A microfluidic platform to design multimodal PEG - crosslinked hyaluronic acid nanoparticles (PEG-cHANPs) for diagnostic applications. Sci. Rep. 10:6028. doi: 10.1038/s41598-020-63234-x

Tang, P., Sun, Q., Yang, H., Tang, B., Pu, H., and Li, H. (2018). Honokiol nanoparticles based on epigallocatechin gallate functionalized chitin to enhance therapeutic effects against liver cancer. Int. J. Pharm. 545, 74-83. doi: 10.1016/j. ijpharm.2018.04.060

Terracciano, M., Shahbazi, M.-A. A. A., Correia, A., Rea, I., Lamberti, A., De Stefano, L., et al. (2015). Surface bioengineering of diatomite based nanovectors for efficient intracellular uptake and drug delivery. Nanoscale 7, 20063-20074. doi: $10.1039 / \mathrm{c} 5 \mathrm{nr} 05173 \mathrm{~h}$

Tian, J., Zhang, H., Liu, M., Deng, F., Huang, H., Wan, Q., et al. (2015). A bioinspired strategy for surface modification of silica nanoparticles. Appl. Surf. Sci. 357, 1996-2003. doi: 10.1016/j.apsusc.2015.09.171

Vaidya, T., Agrawal, A., Mahajan, S., Thakur, M. H., and Mahajan, A. (2019). The continuing evolution of molecular functional imaging in clinical oncology: the road to precision medicine and radiogenomics (Part I). Mol. Diagnosis Ther. 23, 1-26. doi: 10.1007/s40291-018-0366-4

Vetten, M. A., Tlotleng, N., Tanner Rascher, D., Skepu, A., Keter, F. K., Boodhia, K., et al. (2013). Label-free in vitro toxicity and uptake assessment of citrate stabilised gold nanoparticles in three cell lines. Part. Fibre Toxicol. 10:50. doi: 10.1186/1743-8977-10-50

Visalakshan, R. M., Macgregor, M. N., Sasidharan, S., Ghazaryan, A., MierczynskaVasilev, A. M., Morsbach, S., et al. (2019). Biomaterial surface hydrophobicitymediated serum protein adsorption and immune responses. ACS Appl. Mater. Interfaces 11, 27615-27623. doi: 10.1021/acsami.9b09900

Vonarbourg, A., Passirani, C., Saulnier, P., and Benoit, J. P. (2006). Parameters influencing the stealthiness of colloidal drug delivery systems. Biomaterials 27 , 4356-4373. doi: 10.1016/j.biomaterials.2006.03.039

Wang, T., Subramanian, C., Yu, M., White, P. T., Kuai, R., Sanchez, J., et al. (2019). Mimetic sHDL nanoparticles: a novel drug-delivery strategy to target triple-negative breast cancer. Surgery 166, 11681175.

Wang, W., Zeng, C., Feng, Y., Zhou, F., Liao, F., Liu, Y., et al. (2018). The sizedependent effects of silica nanoparticles on endothelial cell apoptosis through activating the p53-caspase pathway. Environ. Pollut. 233, 218-225.

Wu, C. C. C. Y., Lin, J. J., Chang, W. Y., Hsieh, C. Y., Wu, C. C. C. Y., Chen, H. S., et al. (2019). Development of theranostic active-targeting boron-containing gold nanoparticles for boron neutron capture therapy (BNCT). Colloids Surf. B Biointerfaces 183:110387. doi: 10.1016/j.colsurfb.2019.110387

Wu, Q., Miao, T., Feng, T., Yang, C., Guo, Y., and Li, H. (2018). Dextran-coated superparamagnetic iron oxide nanoparticles activate the MAPK pathway in human primary monocyte cells. Mol. Med. Rep. 18, 564-570. doi: 10.3892/mmr. 2018.8972

Xiao, Y., Xu, D., Song, H., Shu, F., Wei, P., Yang, X., et al. (2019). Cuprous oxide nanoparticles reduces hypertrophic scarring by inducing fibroblast apoptosis. Int. J. Nanomed. 14, 5989-6000. doi: 10.2147/IJN.S196794

Yang, Y., Du, X., Wang, Q., Liu, J., Zhang, E., Sai, L., et al. (2019a). Mechanism of cell death induced by silica nanoparticles in hepatocyte cells is by apoptosis. Int. J. Mol. Med. 44, 903-912. doi: 10.3892/ijmm.2019. 4265

Yang, Y., Zhao, W., Tan, W., Lai, Z., Fang, D., Jiang, L., et al. (2019b). An efficient cell-targeting drug delivery system based on aptamer-modified mesoporous silica nanoparticles. Nanoscale Res. Lett. 14:390. doi: 10.1186/s11671-0193208-3
Yang, Y., Meng, Y., Zhang, E., and Ding, J. (2018). A facile way to increase the cellular uptake efficiency of hybrid nanoparticles. J. Nanosci. Nanotechnol. 18, 4559-4564. doi: 10.1166/jnn.2018.15359

Yang, Y., Qu, Y., and Lü, X. (2010). Global gene expression analysis of the effects of gold nanoparticles on human dermal fibroblasts. J. Biomed. Nanotechnol. 6 , 234-246. doi: 10.1166/jbn.2010.1128

Yoo, J., Park, C., Yi, G., Lee, D., and Koo, H. (2019). Active targeting strategies using biological ligands for nanoparticle drug delivery systems. Cancers 11:640. doi: $10.3390 /$ cancers 11050640

Youhannayee, M., Nakhaei-Rad, S., Haghighi, F., Klauke, K., Janiak, C., Ahmadian, M. R., et al. (2019). Physical characterization and uptake of iron oxide nanoparticles of different prostate cancer cells. J. Magn. Magn. Mater. 473, 205-214. doi: 10.1016/j.jmmm.2018.10.062

Yu, Y., Duan, J., Li, Y., Li, Y., Jing, L., Yang, M., et al. (2017). Silica nanoparticles induce liver fibrosis via TGF- $\beta 1 / \mathrm{Smad} 3$ pathway in ICR mice. Int. J. Nanomed. 12, 6045-6057. doi: 10.2147/IJN.S132304

Yue, L., Sun, C., Cheng, Q., Ding, Y., Wei, J., and Wang, R. (2019). Gold nanorods with a noncovalently tailorable surface for multi-modality imageguided chemo-photothermal cancer therapy. Chem. Commun. 55, 1350613509. doi: $10.1039 / \mathrm{c} 9 \mathrm{cc} 07131 \mathrm{~h}$

Yun, C. W., Han, Y. S., and Lee, S. H. (2019). PGC-1 $\alpha$ controls mitochondrial biogenesis in drug-resistant colorectal cancer cells by regulating endoplasmic reticulum stress. Int. J. Mol. Sci. 20:1707. doi: 10.3390/ijms2007 1707

Zhang, C., Lu, J., Tian, F., Li, L., Hou, Y., Wang, Y., et al. (2019). Regulation of the cellular uptake of nanoparticles by the orientation of helical polypeptides. Nano Res. 12, 889-896. doi: 10.1007/s12274-019-2319-6

Zhang, X., Shen, Y. P., Li, J. G., and Chen, G. (2019). Clinical feasibility of imaging with indocyanine green combined with carbon nanoparticles for sentinel lymph node identification in papillary thyroid microcarcinoma. Medicine 98:e16935. doi: 10.1097/MD.0000000000016935

Zhang, L., Sun, S., Wang, Y., Mo, Y., Xiong, F., and Zhang, S. (2020). Gossypol induces apoptosis of multiple myeloma cells through the JUN-JNK pathway. Am. J. Cancer Res. 10, 870-883.

Zhang, L., Xue, H., Cao, Z., Keefe, A., Wang, J., and Jiang, S. (2011). Multifunctional and degradable zwitterionic nanogels for targeted delivery, enhanced MR imaging, reduction-sensitive drug release, and renal clearance. Biomaterials 32, 4604-4608. doi: 10.1016/j.biomaterials.2011.02.064

Zhang, X. F., Huang, F. H., Zhang, G. L., Bai, D. P., de Felici, M., Huang, Y. F., et al. (2017). Novel biomolecule lycopene-reduced graphene oxidesilver nanoparticle enhances apoptotic potential of trichostatin A in human ovarian cancer cells (SKOV3). Int. J. Nanomed. 12, 7551-7575. doi: 10.2147/ IJN.S144161

Zhang, Y., Li, X., Huang, Z., Zheng, W., Fan, C., and Chen, T. (2013). Enhancement of cell permeabilization apoptosis-inducing activity of selenium nanoparticles by ATP surface decoration. Nanomed. Nanotechnol. Biol. Med. 9, 74-84. doi: 10.1016/j.nano.2012.04.002

Zhao, C. Y., Cheng, R., Yang, Z., and Tian, Z. M. (2018). Nanotechnology for cancer therapy based on chemotherapy. Molecules 23:826. doi: 10.3390/ molecules 23040826

Zhu, T., Shi, L., Yu, C., Dong, Y., Qiu, F., Shen, L., et al. (2019). Ferroptosis promotes photodynamic therapy: supramolecular photosensitizer-inducer nanodrug for enhanced cancer treatment. Theranostics 9, 3293-3307. doi: 10. 7150/thno.32867

Conflict of Interest: The authors declare that the research was conducted in the absence of any commercial or financial relationships that could be construed as a potential conflict of interest.

Copyright (c) 2020 Sanità, Carrese and Lamberti. This is an open-access article distributed under the terms of the Creative Commons Attribution License (CC BY). The use, distribution or reproduction in other forums is permitted, provided the original author(s) and the copyright owner(s) are credited and that the original publication in this journal is cited, in accordance with accepted academic practice. No use, distribution or reproduction is permitted which does not comply with these terms. 